The 4th International Eastern and Western Summit of Writers, Translators and Critics 第四届东方与西方国际作家、翻译家、评论家高峰论坛

\title{
Classical Chinese Theatre for Different Times: French Translations and Retranslations
}

\author{
Rainier LANSELLE
}


- André Lefevere, Translation, Rewriting, and the Manipulation of Literary Fame, 1992

- a. Translation [of any kind] is nothing but a form of rewriting

- "Translation is the most obviously recognizable type of rewriting."

- "It is potentially the most influential because it is able to project the image of an author and/or a (series of) work(s) in another culture."

- b. Rewriting is powerful

- "These images existed side by side with the realities they competed with, but the images always tended to reach more people than the corresponding realities did."

- "The power wielded by these images [...] is enormous." 
- Jesuits in China

- Vectors of cultural transmission

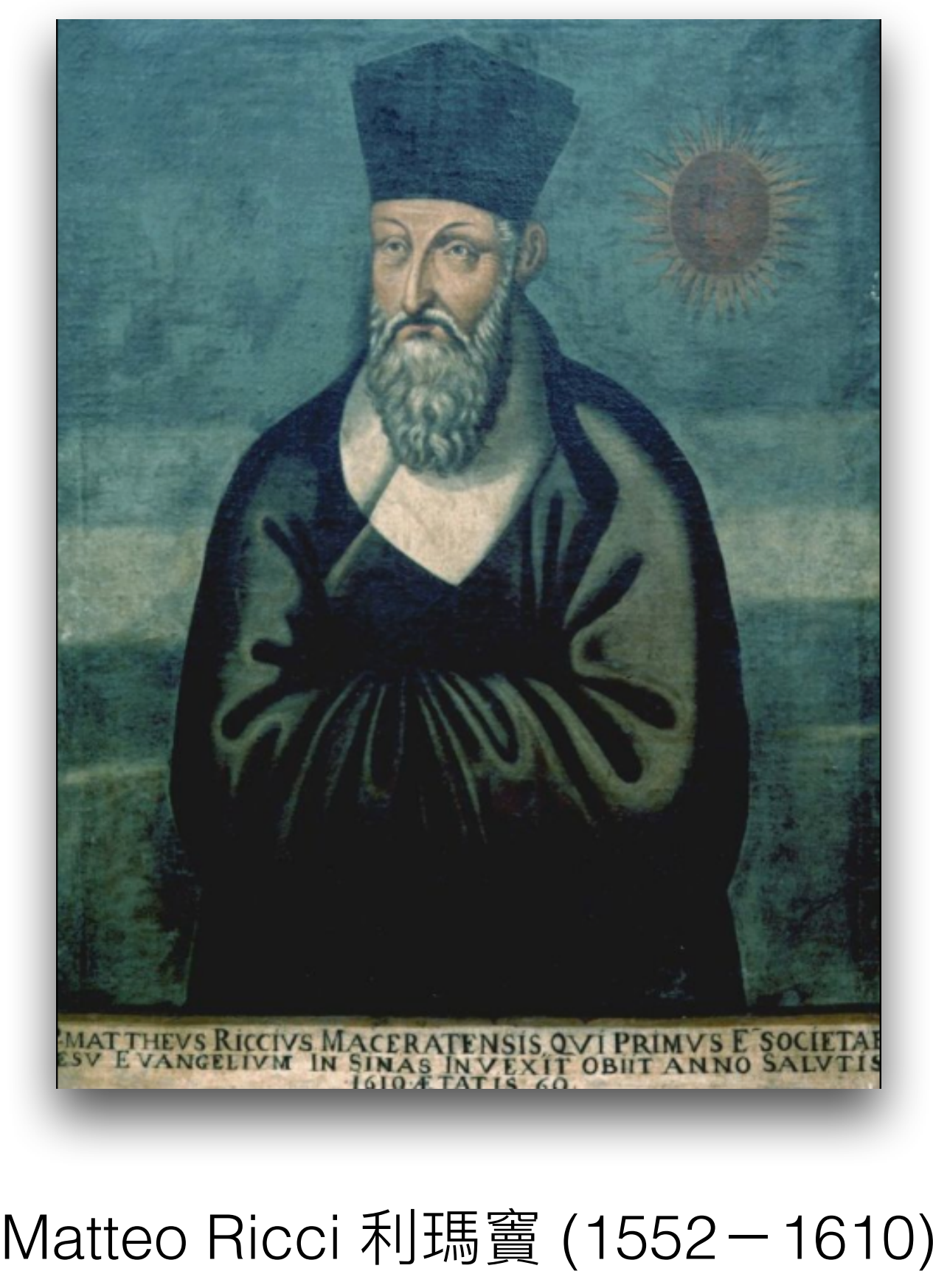

- Systematic effort to "translate China" for European audience 


\section{CONFUCIUS}

$S$ I N A R U M

\section{PHILOSOPHUS,}

\section{S: I V E}

S C I E N T I"A S I N E N S I S LA TI NE EXPOSITA.

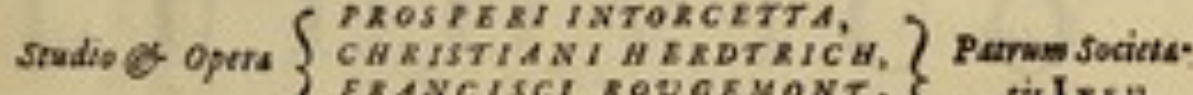
FRANCISCI ROUOEMONT,
PAILIPPI COUPLET,

$$
\text { J o s S } 0
$$

L U D O I C I M A G N

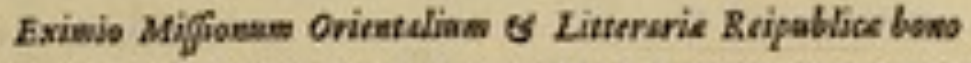
E BIBLIOTHECA REGIA IN LUCEM PRODIT. ADFICTA EST TASULA CHRONOLOGICA SINICA MONARCHIA

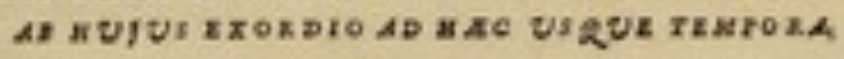

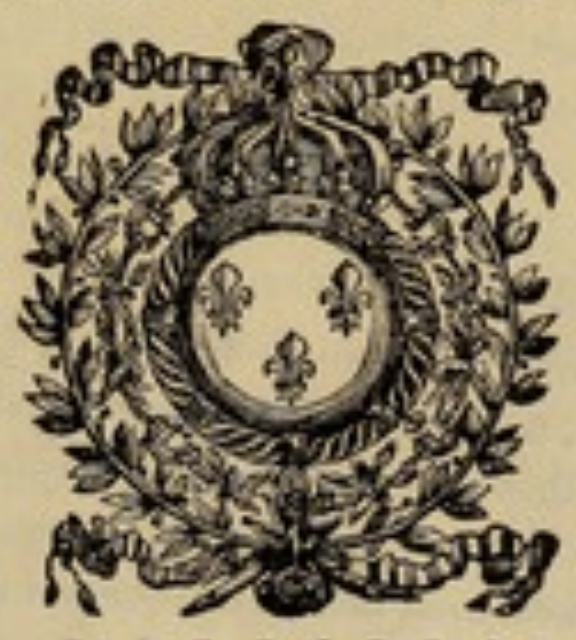

$P$ A R I S I I S, Apud DANiELEM HORTHEMELS, vià Jacobrà, fub Macenate.
- First complete translation of the Four Books 四書

- 1687

-1687-1703 : about 30 French Jesuit missionaries in China 
- Jean-Baptiste Du Halde (1674-1743)

- Geographical, historical, chronological, political, and physical description of the Chinese empire and Chinese Tartary

- 1735

\section{E S C R I P T I O N} GEOGRAPHIQUE, HISTORIQUE, CHRONOLOGIQUE, POLITIQUE, ET PHYSIQUE

DE L'EMPIRE DE LA CHINE E T T E L L A

TARTARIE. CHINOISE, ENRICHIE DES CARTES GÉNÉRALES ET PARTICULIERES de ces Pays, de la Carte génénale \& des Cartes particulieres du Thibet, $\&$ de la Corte; \& ornće d'un grand nombre de Figures \& de Vignettes gravées en Taille-douce.

Par le P. J. B. DU HALDE, de la Compagnic de Jesus.

Avec un Avertiftement peelininaire, oú rea rend compte des principales umeliorations qui ent cté faites dans cettc Nouvelle Edition. T OME PREMIER.

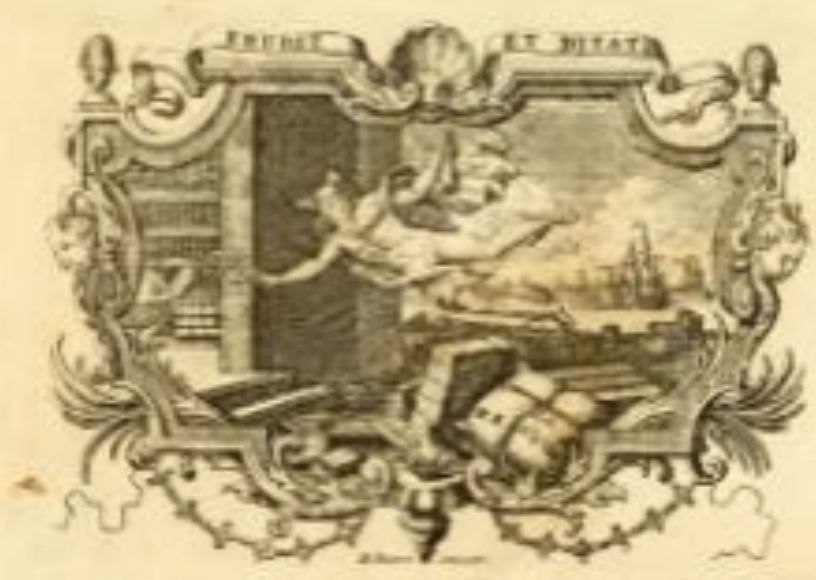

$$
\text { A LA HATE, }
$$

Chez HENRI SCHEURLEER. N. DCC. $\times \times \times \mathrm{v}$, 
- Edifying and curious letters written by some Missionaries of the Society of Jesus from foreign Missions

- $1702-1776$

- 34 volumes

\section{E T T R E S}

EDIFIANTES ET CURIEUSES,

É C R ITES

PAR DES MISSIONNAIRES,

$D E$

LA COMPAGNIE DE JÉSUS.

MÉMOIRES DE LA CHINE.

L E T T R E

Du Père d'Entrecolles, 'Missionnaire de la Compagnie de Jésus, au Révérend Père Duhalde, de la meme Compagnie.

A Pekin, le 11 Mai ${ }_{1726}$

Mon révérend pére,

La paix de N.S.

Ev lisant depuis peu lés Mémoires de Trévoux de l'année rj24, je suis tombé sur l'extrait d'une lettre de M. de la Coste, dans laquelle il parle de l'insertion ou inoculation de la petite vérole; et je me suis

A 3 
- 18th cent.: Age of Enlightenment

- "China craze"

$\rightarrow$ In search of different social, aesthetic, and political models

- Montesquieu (1689-1755)

- Diderot (1713-1784)

- Beaumarchais (1732-1799)

- Condorcet (1743-1794)

- Voltaire (1694-1778) 
- 1735:

- "Tchao Chi Cou Ell, or The Little Orphan of the House of Tchao - Chinese tragedy"

- 趙氏孤兒大報仇 The Great Vengeance of the Orphan of the Zhao Clan, by Ji Junxiang 紀君祥 (Yuan dyn.)

- Translator: Father Joseph-Henri-Marie de Prémare (1666-1736), Jesuit

- First Chinese play translated into any European language

- Highly "unfaithful" translation (no translation of the arias)

$\rightarrow$ The story caught the imagination of Europeans, and became the basis for adaptations/rewritings over the next few decades in many European languages (English, German...) 
- Berman and Bensimon

- Monographic volume of the journal Palimpsestes on retranslation (1990)

- "Retranslation Hypothesis" (RH) (as defined by Chesterman, 2000)

$\rightarrow$ The first translation of a literary text is more target language oriented vs. / retranslations are nearer to the source text and language.

- The function of the first translation is to introduce the work into the target culture

- It has to be comprehensible for a reader who is not familiar with the culture of the source text 


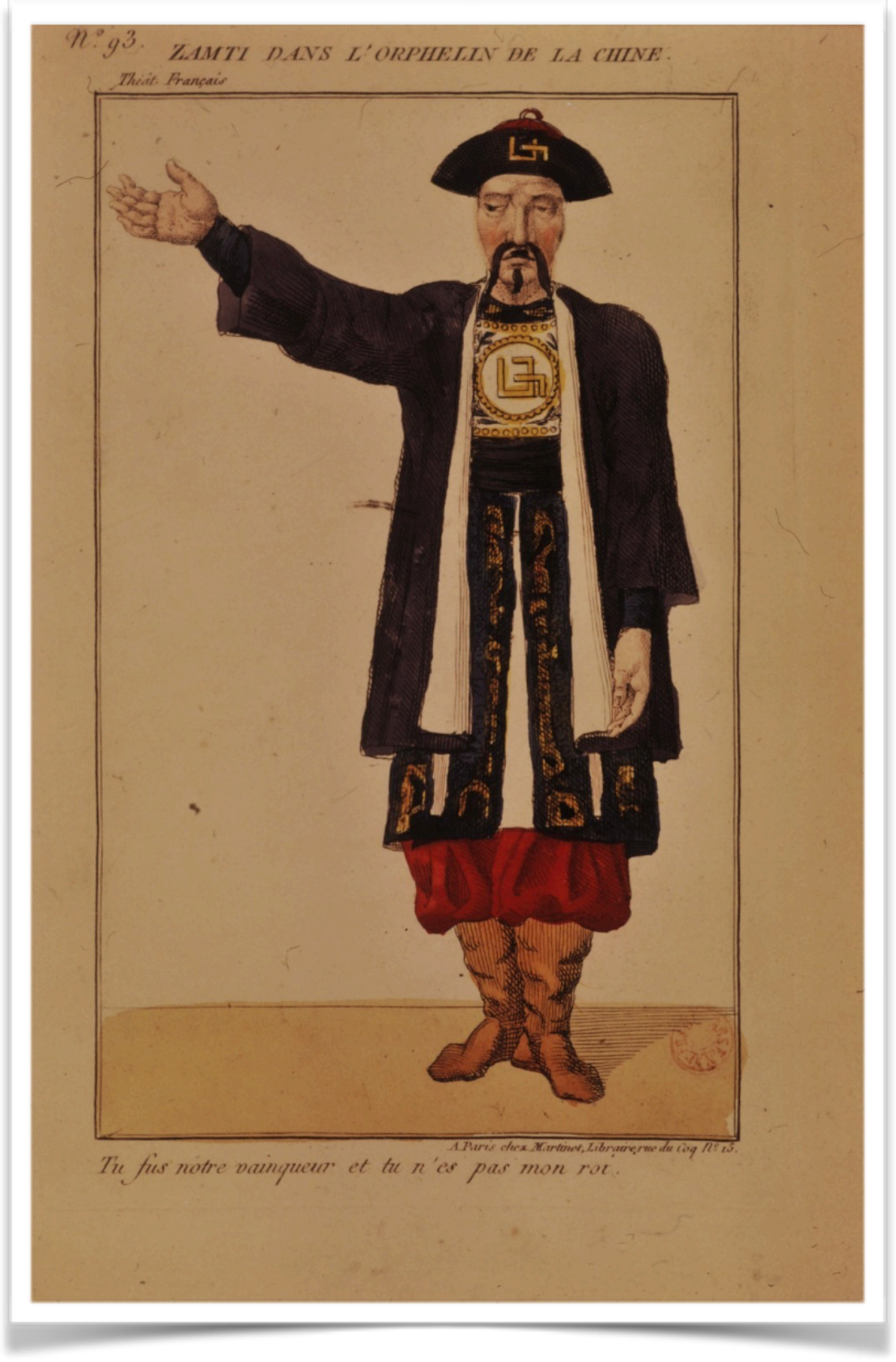

- 1755

- Voltaire (1694-1778)

\section{L'OR PHELIN}

DE

\section{LA CHINE,}

TRAGEDIE DE VOLTAIRE

Repréfentée pour la premiere fois d Paris, le 20 Aodit 1755.

Avec deux lettres critiques.

L'O R P HELI

D E L A C H I T R A GE D IE. Repréentée pour la premiére fois à
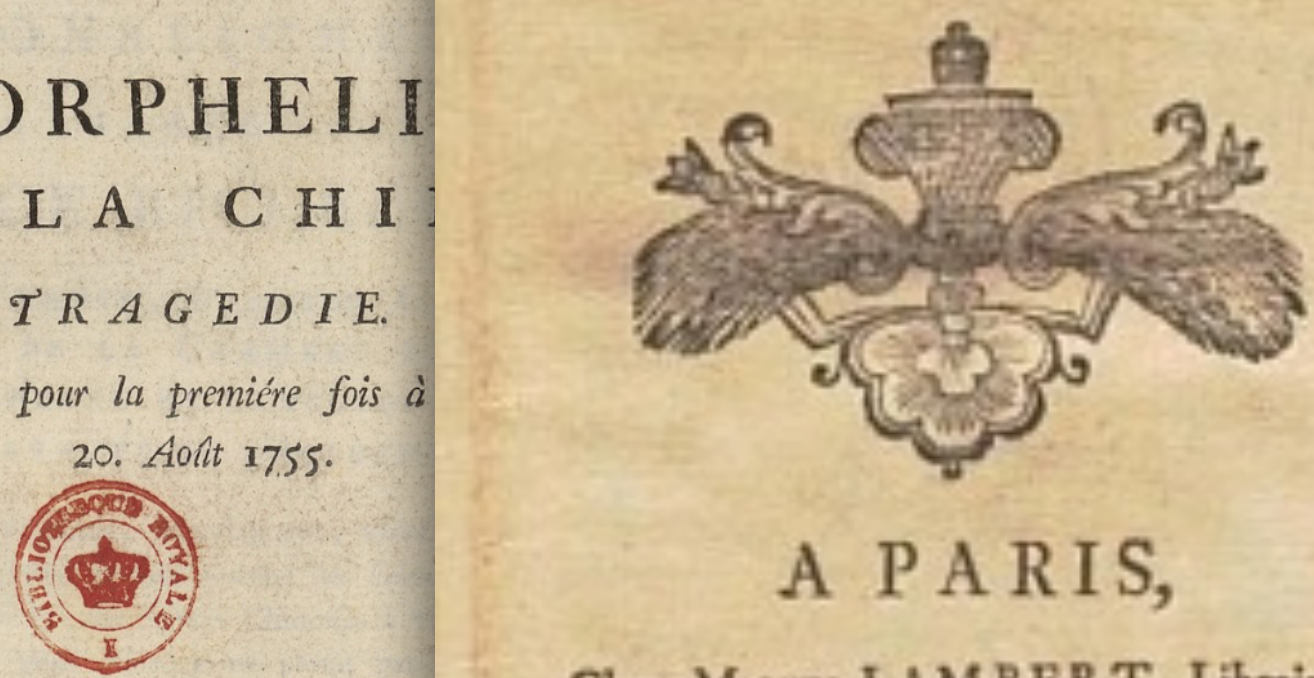

A PARIS,

Chez Mrenre LA M BER T, Libraire, rue \& â eôté de la Comédie Françoife, au Parnafte.

- The Orphan of China Confucius' morality in five acts 
• 1755

- Voltaire's The Orphan of China's first public reading

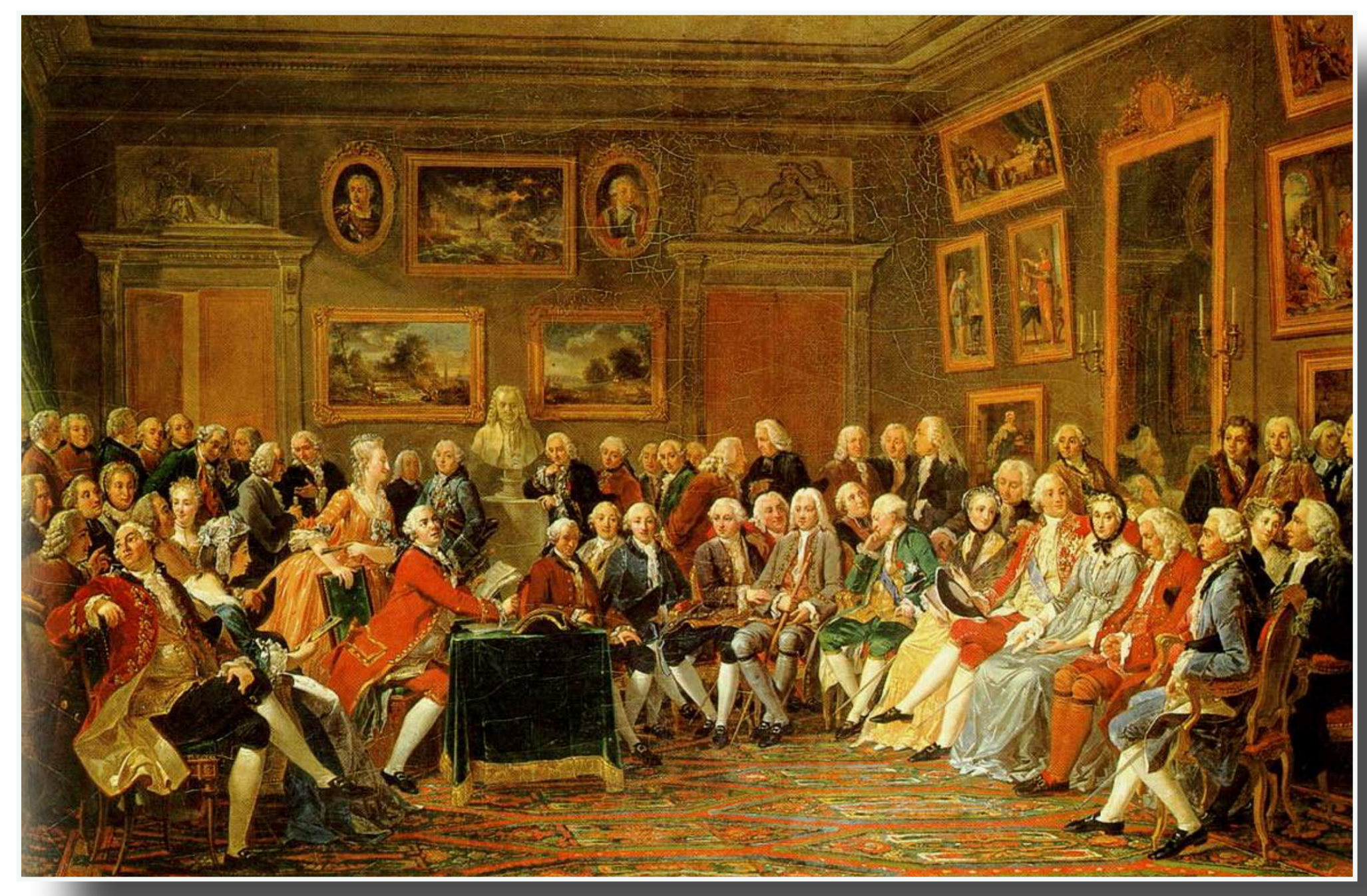

$\rightarrow$ Note the practice of reading aloud a theater play in a "salon" instead of performing it onstage

- This practice will last until the end of the 19th cent. and will have a huge impact on the reception of Chinese theater 
- The importance acquired by the Orphan of Zhao is a striking illustration of Lefevere (1992) as quoted above on the influence of rewriting as compared with the original

- The translation / rewriting of the play, however "unfaithful", had a comparatively far greater impact than the play ever had in China itself

- The influence of the translation went far beyond the French language, as the first translations in other European languages, including English, were made from the French version and not from Chinese 
- "Translations provide a tool for cultural interaction that shows certain synchronous aspects of the target culture at a given time. This idea is related to the concept of polysystems associated with the School of Manipulation, which states that in translation, the literary text is manipulated according to the target culture."

(Cadera, 2017, commenting Bassnett and Lefevere, 1990)

- Voltaire's own play can be seen as a commentary of the Chinese "original"

$\rightarrow$ "There is no point where translation stops and adaptation starts."

(Ladmiral, 2014)

- Many stories (e.g. from the great novelist Feng Menglong 馮夢龍, 1574-1646) were translated in a way that completely decontextualized them and presented them as illustrations of the Chinese moral/ethical system 
- After the French Revolution (1789-1799)

- Complete upheaval of the way foreign cultures were dealt with 
- French campaign in Egypt and Syria

- (1798-1801)

- Military expedition + scientific discovery

- 167 scientists and engineers
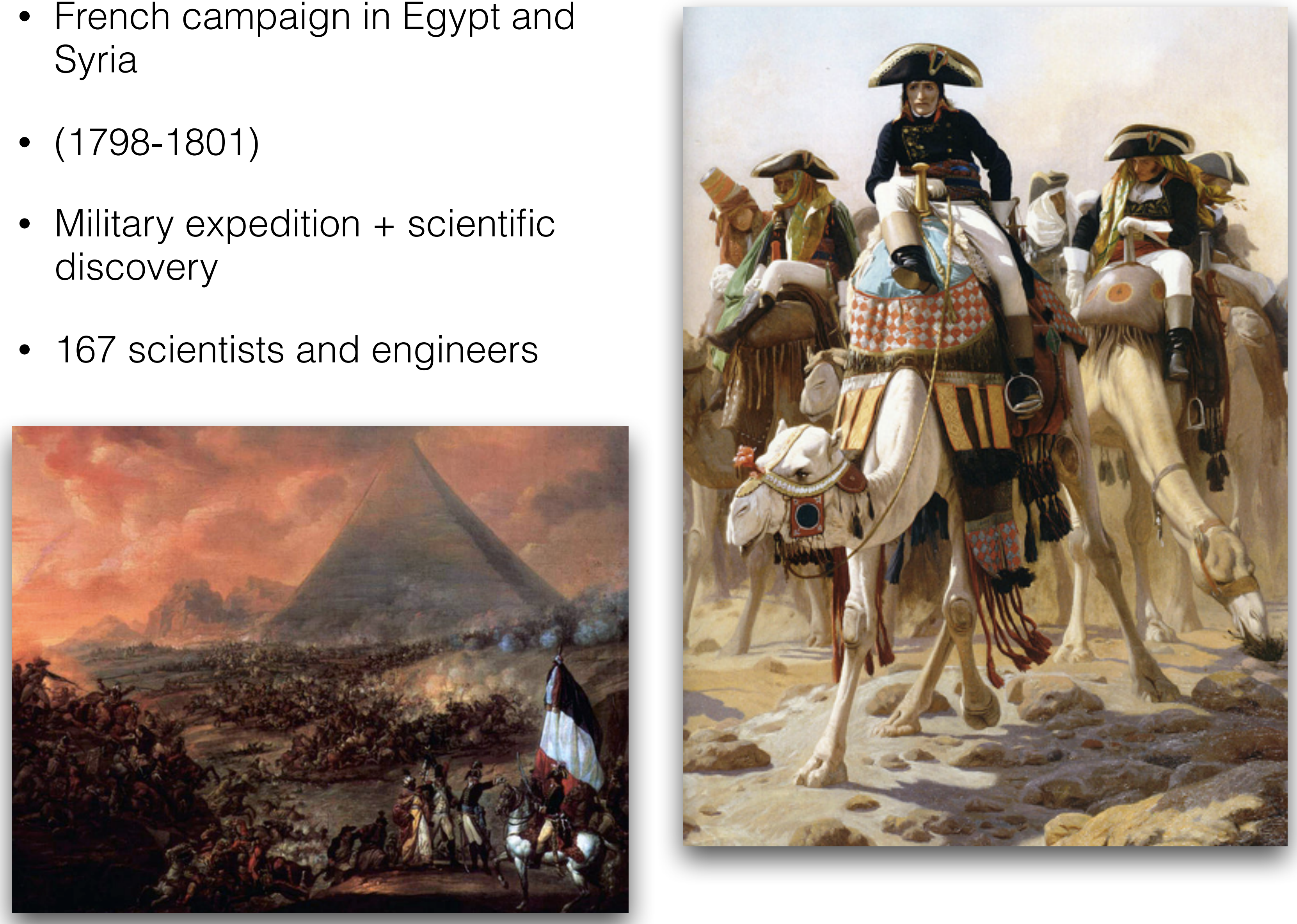
- Description of Egypt

- Publication 1809-1826

- 37 volumes

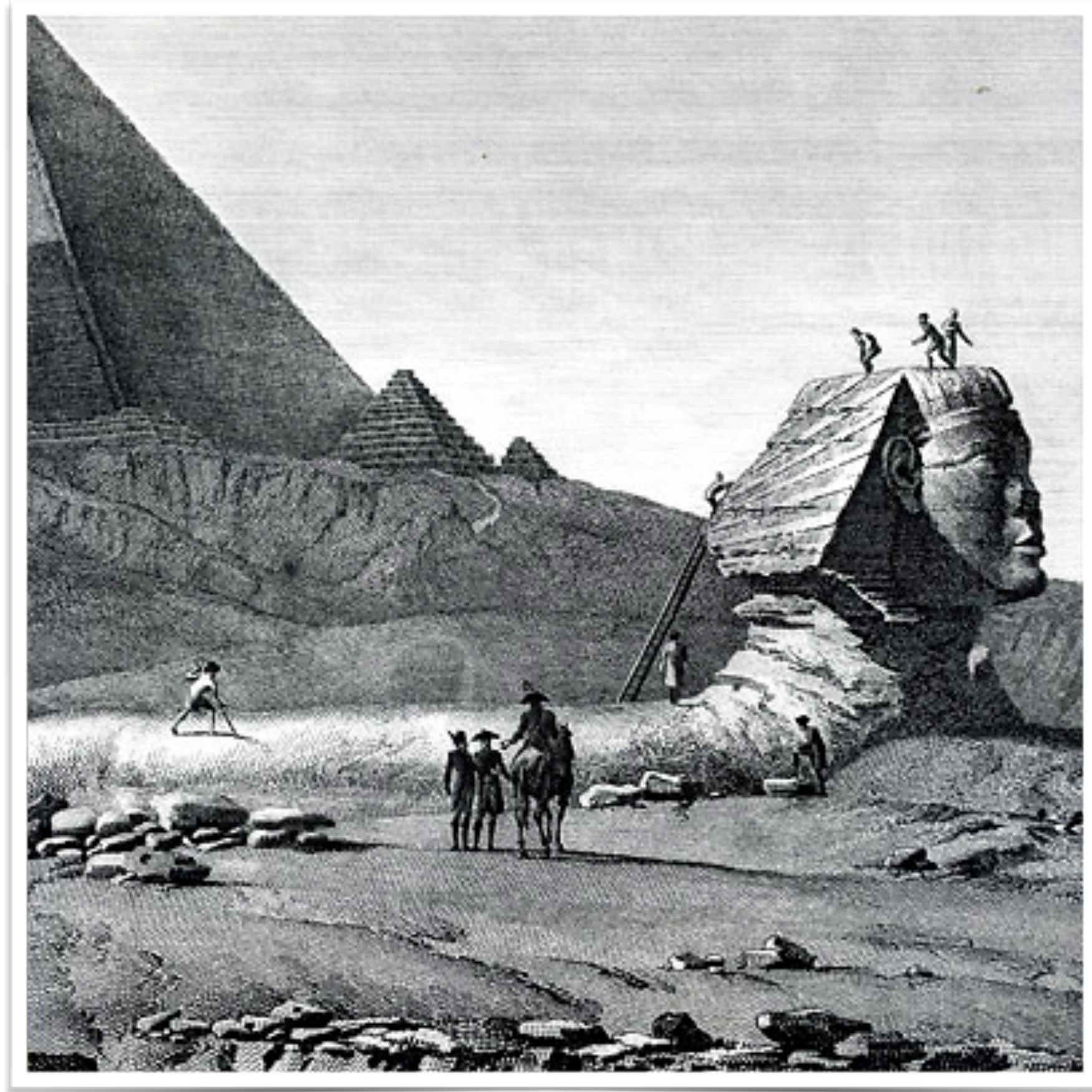

\section{DESCRIPTION}

DE L'ÉGYPTE, ou

RECUEIL

DES OBSERVATIONS ET DES RECHERCHES QUI ONT ETK FAITES ES EGYPTI

PENDANT LEEPEDITION DE LARMEE TRANCAISE, PUBLit

PAR LES ORDRES DE SA MAJESTE L'EMPEREUR NAPOLÉON LE GRAND.
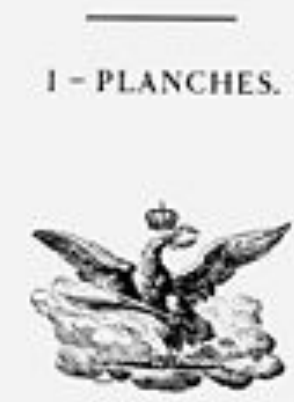

A PARIS.

DE LIMPRIMERIE IMPÉRIALE. $x$ DCCE ix

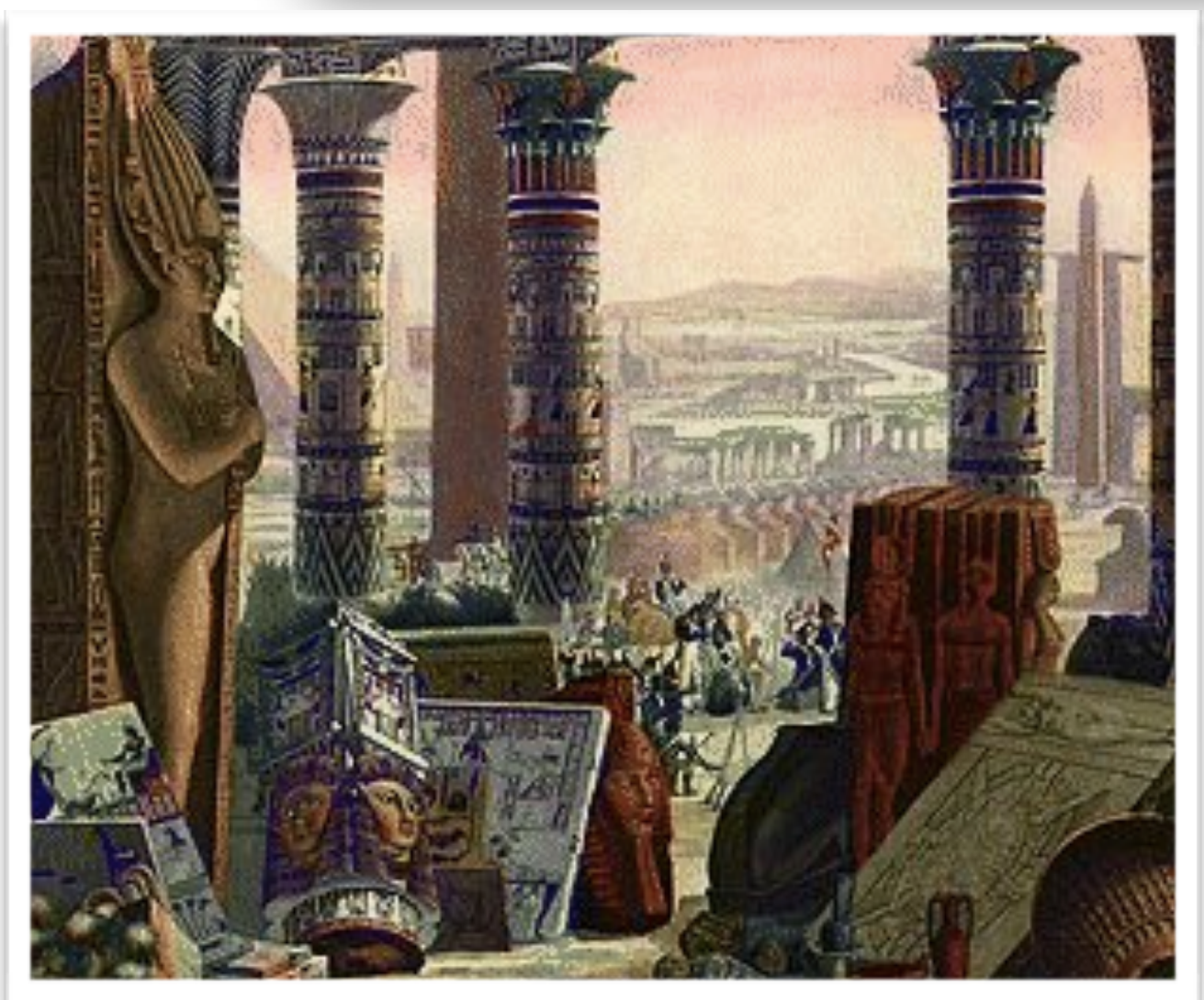




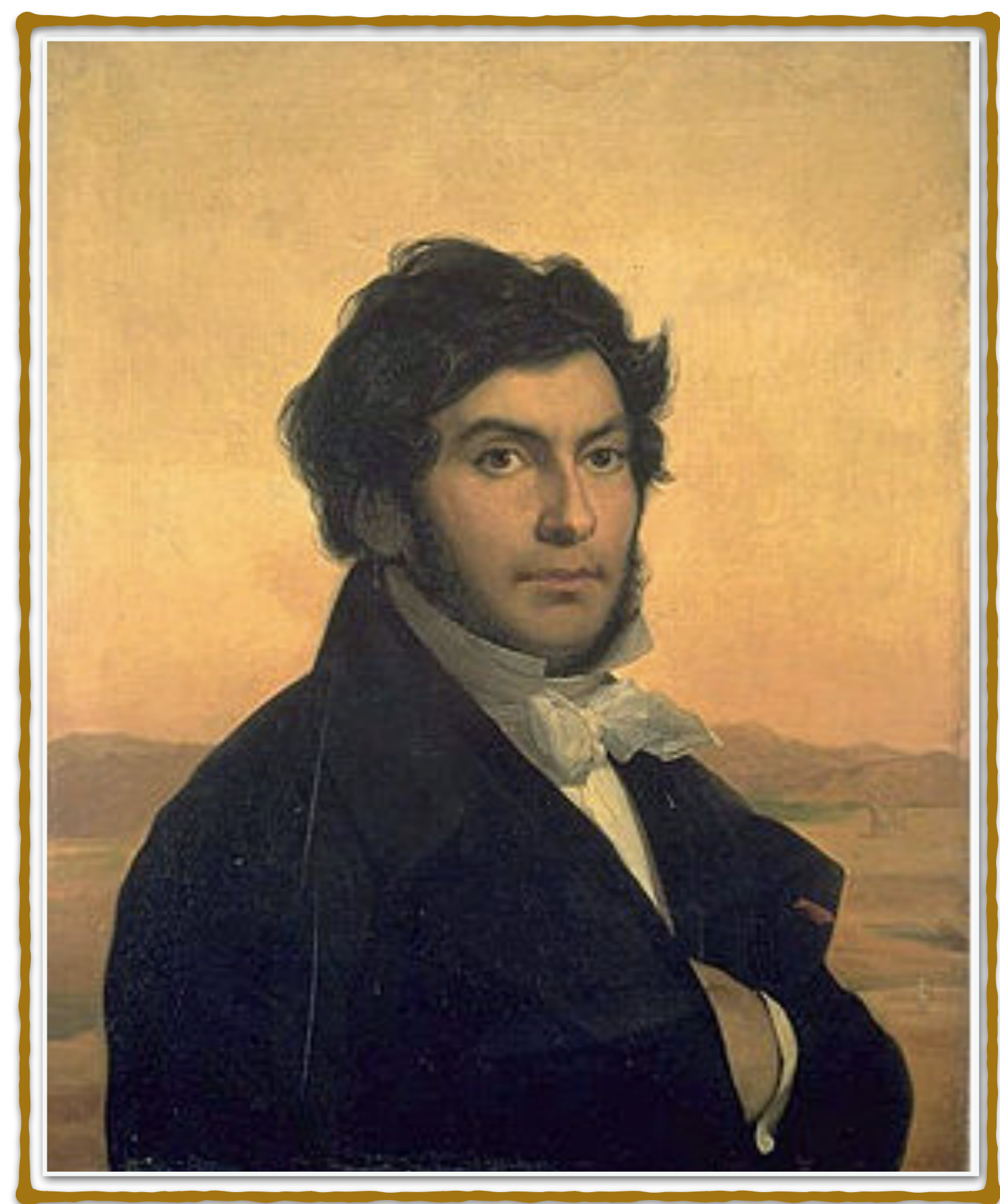

- Jean-François Champollion (1790-1832)

- Decipherer of Egyptian scriptures from the Rosetta Stone

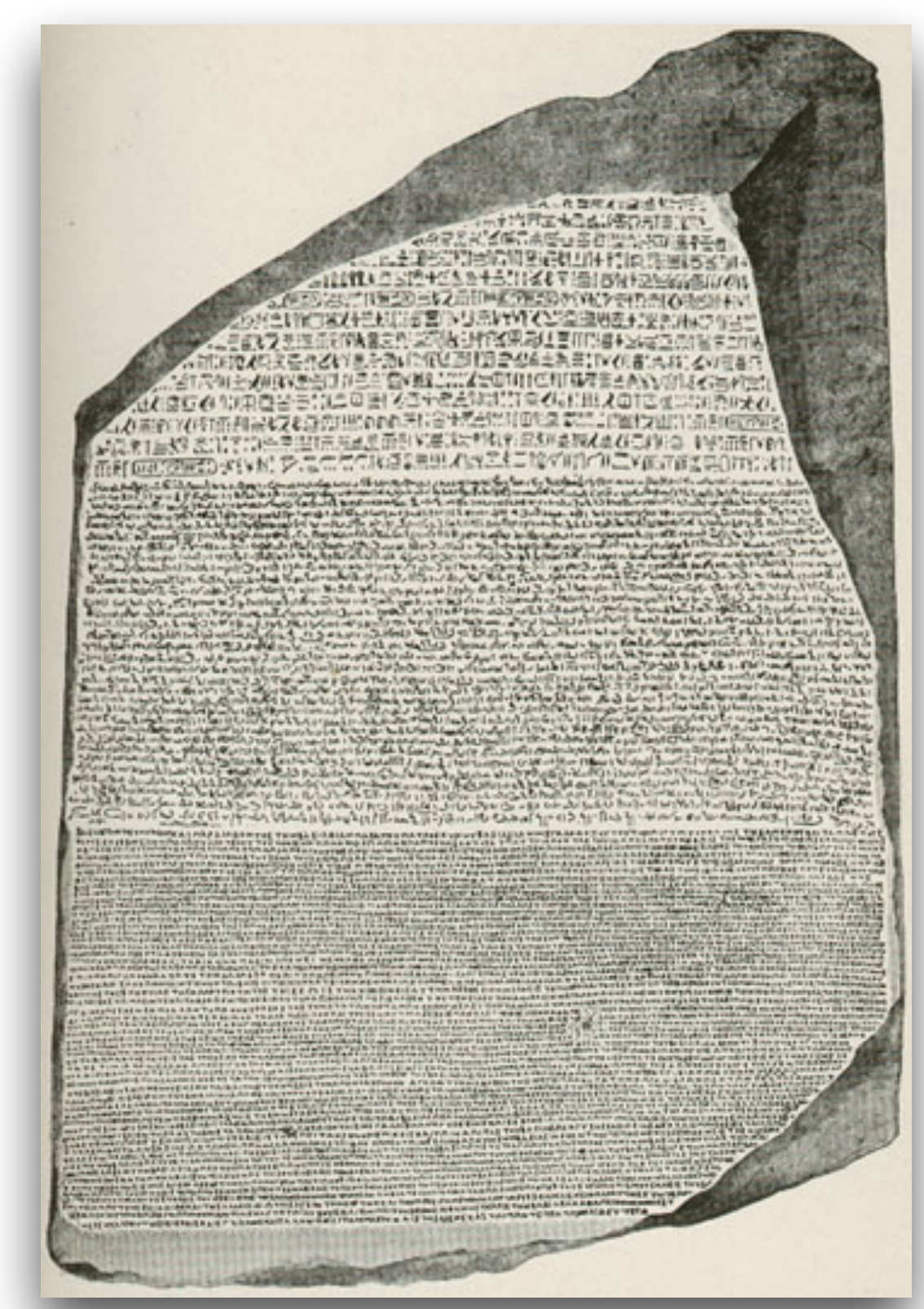


- Scientific scrutiny of foreign civilizations

- Based on documents rather than on personal experience

- Scientific analysis of foreign languages + Developement of philology

$\rightarrow$ Whereas Jesuit missionaries would spend $30 / 40$ years in foreign countries, modern scholars could now devote their entire lives to the study of foreign civilizations without ever setting foot in the related countries (this was to be the case for many sinologists)

- Ideology of romanticism: discover / rediscover / reconstruct "faraway" civilizations (in time of distance)

- Direct field contact is replaced by the study of documents and the creation of large libraries

- Views on translation change radically as compared with the previous period 
- Creation of academic positions

- New institutions:

- "Special School of Oriental Languages" (Established 1795, still extant)

- Old instituions teaching new disciplines:

- Collège de France (Established in 1530, still extant)

- In the nascent sinology, two names are particularly noteworthy in regard with Chinese theatre translation:

- Stanislas Julien

- Antoine-Pierre-Louis Bazin 
- Stanislas Julien (1797-1873)

- Chair of "Chinese Language and Literature and Manchurian Tartar"

- 1832-1873

- Like his predecessor Jean-Pierre AbelRémusat (same chair, 1814-1832), never went to China in his entire life 
- Julien was a prolific author and translator

- Books on

- Chinese grammar

- history

- Chinese sciences and techniques

- Translations include

- relgious texts

- numerous works of vernacular literature

- Yuan (Mongol period, 13th-14th cent.) plays

\section{記闌灰}

H O E İ-L A N-K I,

L'HISTOIRE DU CERCLE DE CRAIE,

DRAME EN PROSE ET EN VERS,

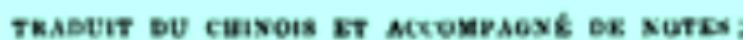

Pal STANISLAS JULIEN.

1832

The Circle of Chalk by

Li Qianfu 李潛夫 (13th cent.) 
- 趙氏孤兒大報仇 The Great Vengeance of the Orphan of the Zhao Clan

- 1834

- Historical drama in prose and verse

NoUVEH.r. ET DE. ROESIES

cescost

PAR STANASLAS JULES

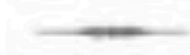

Pans

- $\rightarrow$ First complete translation of the play

- Julien is obviously challenging the translator of 1735 
- Dean-Cox, 2014 quotes St Andre, 2003 on "retranslation as challenge"

- "Focus on the Chinese novel Haoqiu zhuan 好述傳 reveals how Sir John Francis Davis sets his 1829 English retranslation in opposition to the initial English translation in 1761 by Percy (a British merchant) by reinforcing the corrective properties of his own version, and simultaneously arguing against the legitimacy of the first attempt."

- "St Andre further shows how rivalry may reach across target culture borders. The first English translator of Foguo ji 佛國記, a fifth-century account of the travels of a Chinese Buddhist monk, works not from the original text, but from a French translation. The tension between the two Sinologist traditions is evident in the replacement of French scholarship [...] with supposedly superior English expertise. There follows four English retranslations, all of which go to great lengths to underscore the errors of their predecessors and thereby lay claim to their own validity."

(Deane-Cox, 2014) 
- Xixiang ji 西廂記 The Story of the Western Wing

- By Wang Shifu 王實甫 (fl 1297-1307)

- Very important opus

- Was the archetype of Chinese love stories, influencing 700 years of sentimental fiction \& theater

- 1872

- The Story of the Western Pavilion - Comedy in sixteen acts

- First full translation in a European language

- In relation with Julien's teaching at the Collège de France

$\rightarrow$ Scholarly translation:

- text of arias is reproduced in Chinese in the translation

- heavily footnoted

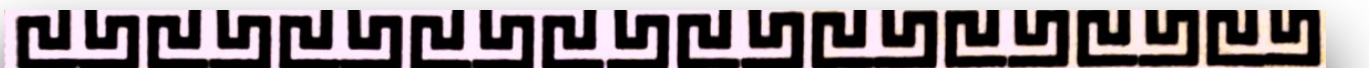

氝

L'HISTOIRE DU PAVILLON D'OCCIDENT

COMÉDIF FN SFIZF ACTES

TRADUIT DU CHINOIS PAR

STANISLAS JULIEN

EXTRAIt DE LAATSJME GJSA

$1872-80$ 


\section{ACTE SECOND.}

Sa figure est celle d'un jeune homme; il sait entretenir sa vic ${ }^{\star}$.

面如少年得内差

\section{Son aspect est noble et imposant. 貎 学 学}

Sa voix est forte et éclatante ;

\section{馨 朗 朗}

Il ne lui manque que l'auréole d'un saint;

On dirait la statue de Sanghas.

\section{便是揘塑的僧伽像}

\section{FA-PEN}

Veuillez, Monsieur, entrer dans ma cellule ${ }^{6}$. Hier soir, ce

LLitt. "il sait nourrir son intérieur. " le propre fils du Bouddha. Dans notre On lit dans le philosophe Tchoang-tseu, passage, on pourrait donc voir l'image du chap. Yang-seng, ou de l'Art de nour- Sangha personnifié. Cependant une note rir, entretenir sa vie: Pao-chi-hong, de notre texte dit que dans l'Inde, Sangha quoique âgé de soixante-dix ans, avait le désigne un grand maitre, un grand lettré tcint d'un jeune enfant.

(Ta-sse), mass elle ne nous apprend pas

sEn chlnois: Seng-kia, sons qui figu- si c'est une expression générale ou une rent Sangha, l'assembléc, la rćunion des expression particuliere, appartenant à un auditcurs. Les bouddhistes rendaient un maître déterminć. Nous voyons dans le culte aux trois objets précieux (en chinois, Peï-wen-yun-fon, liv. xx, fol. 115, que San-pao), savoir: au Bouddha, à la Loi ct à l'Asscmbléc (en sanscrit, Bouddha, Sangha, Dharma). Suivant Eug. Burnoul Introd. au Bouddh., p. 221), le Sangha, ou l'Assembléc, considérć sous un point le vuc tout mythologique, était nommé
SI-SIANG-KI.

30 vicux religicux etait absent, et il a manque l'occasion d'aller au devant de vous.

\section{TCHANG-SENG}

Cet humble étudiant connaissait depuis longtemps votrc pure renomméc. Il était venu pour entendre, au bas de votre fauteuil, vos sages instructions. Hier soir, contre son attente, il vous a manmais aujourd hui qu'il vous a vu, il a obtenu le bonheur qu'il rêrait dans ses trois existences ${ }^{7}$ passées.

\section{FA-PEN}

J'oserai vous demander quels sont vos ancêtres; quel est votre illustre nom de famille et votre noble nom d'enfance, et pourquoi vous êtes venu ici.

\section{TCHANG-SENG}

Cet humble étudiant est originaire de la partie occidentale de Lo-yang; son nom de famille est Kong, et son nom honorifique Kiun-chouï. Il a passé par ici en allant à la capitale pour subir ses examens.

carrés. Cette expression qui signifie ordi- Pi-ye (Vaicalì), il rendit visite au religieux' nairencent un couvent bouddhique, dési- Weï-mo (Vinalakîrti) qui habitait une gne ici la cellule d'un religieux. Voici chambre creusce dans un rocher. L'ayant inrigine de cette acception. Sous la dynas- mesurce en long et en large, il trouva tie des Thang, dans la période hien-khing qu'clle avait dix pieds carrés (fang-tchang) (656-660, Wang-youen-tse fut envoyé en ${ }^{7}$ Allusion aux existences antéricures mission dans l'Inde. Quand il fut arrivè à qu'admettent les bouddhistes. 
- Access to the reality of another culture through the treatment of literary allusions

- $\rightarrow$ "On the whole, most translators do not try to convey the literary allusions, except in an "explanatory note." Maybe because allusions point to the final, real aporia of translation, the real untranslatable, which does not reside in syntactic transfers or semantic constructions, but rather in the peculiar way in which cultures all develop their own "shorthand," which is what allusions really are."

(Lefevere, 1992) 
- Antoine-Pierre-Louis Bazin (1799-1863) ("Bazin The Elder")

- Professor of Chinese, School of Oriental Languages

- President of the Société Asiatique (Founded 1822, still extant) 
- Author of books on Mongol (Yuan) period theater and Chinese vernacular language

- Chinese theatre composed under the Mongolian emperors (1838)

- The Century of Youen, or Historical Table of Chinese Literature, from the advent of the Mongolian emperors to the restoration of the Ming (1850)

- Treaty on the general principles of vernacular Chinese (1845)

\section{THÉATRE CHINOIS}

CHOIX DE PIÈCES DE THÉATRE

SOUS LES EMPEREURS MONGOLS

TRADUITES POUR LA PREMIĖRE FOIS SUR LE TEXTB ORIGINAL

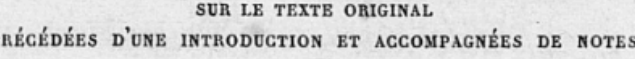

PAR M. BAZIN AINÉ'

MEMBRE DE LA SOCIÉTÉ ASIATIQUE DE PARIS

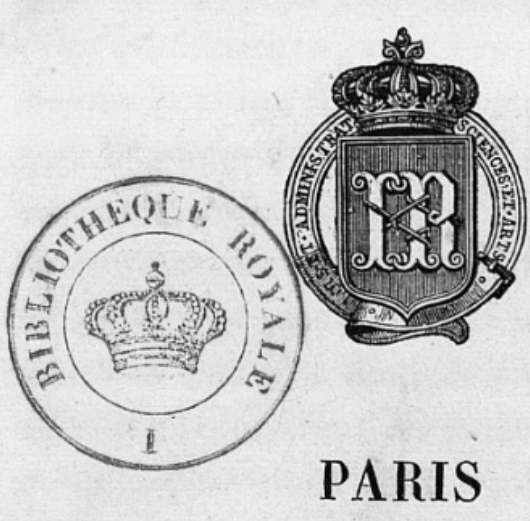

IMPRIMÉ PAR AUTORISATION DU ROI

A L'IMPRIMERIE ROYALE

M DCGC XXXVIII 


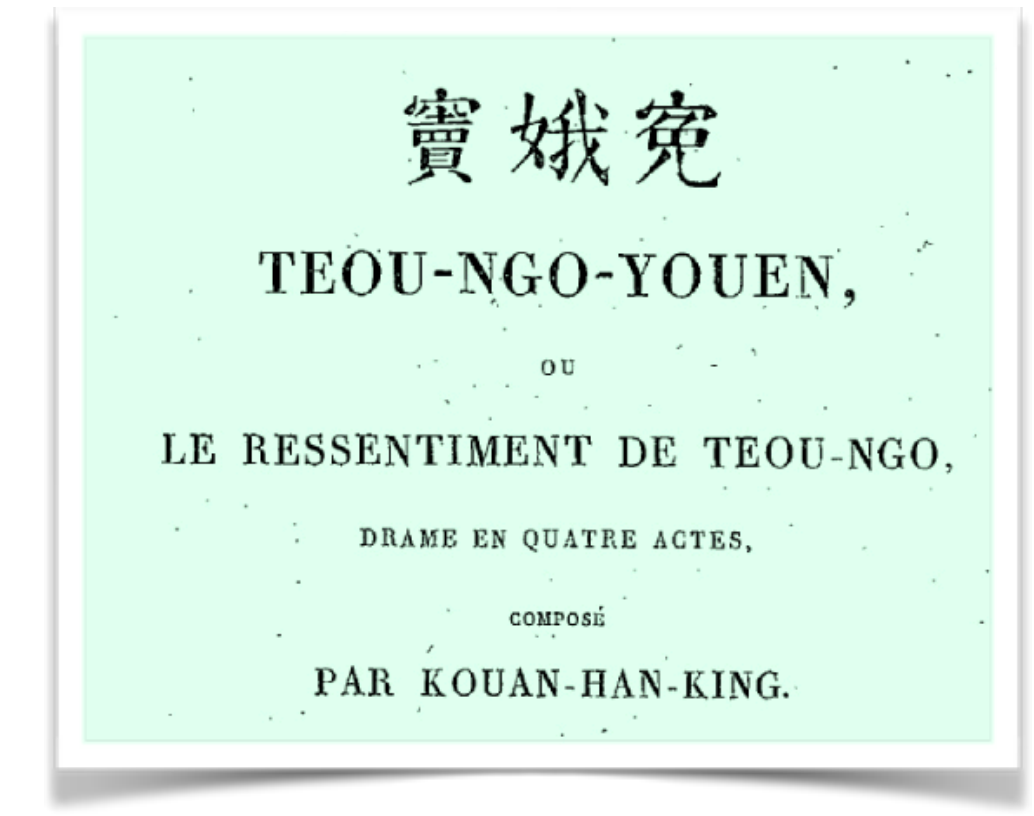

- Translator of a great amount of classical plays, including:

- 竇娥冤 The Injustice to Dou E, by Guan Hanqing (c. 1241-1320), 關漢卿

- 琵琶記 The Story of the Lute, by Gao Ming 高明 (1305-1359) (1841)

\section{LE PI-PA-KI}

L'HISTOIRE DU LUTH

DRAME CHINOIS DE KAO-TONG-KIA

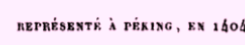

AVEC LES CHANGEMENTS DE MAO-TSEU

TANDUT SUR LE TEXTE ORGIIAN

PAR M. BAZIN AINÉ

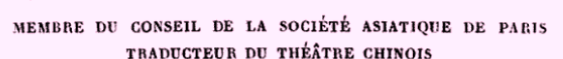

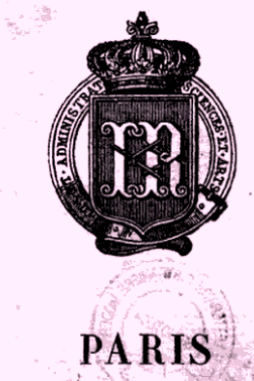

INPRINÉ PAR AUTORISATION D

A L'IMPRIMERIE ROYYALE

M DCCC XLI 
- Li Shengfeng 李声凤, 2015

• (中国戏曲在法国的翻译与接受(1789-1870), Translation and reception of Chinese theatre in France (1789-1870)

- Provides an exhaustive list:

- 113 classical Chinese plays have have given way to publications in France between 1819 and 1880:

- translations (complete / partial)

- plot summaries 
- Multiple reasons for 19th century attraction for theatre

- Theatre was then the popular entertainment par excellence

- Everyone goes to the theater

- Drama is considered having an exemplary / teaching value

- Theater was one of the easiest ways to mediate the general public's huge interest for things Chinese

- Taste for epistolary novels

- Chinese plays were never performed (there was no way to ensure Chinese opera's musical staging), but read, either individually or in public readings ( $\rightarrow$ "salon", i.e., parlour practices)

$\rightarrow$ This is a huge difference with Molière's destiny in China, where translations were made in priority for the stage, not only for reading

(Zhang Qiang 2016) 
- Huge changes in Sinology at the turn of the 20th century

- Need for acurate translations of philosophical, religious, historical documents

- Developement of interest in hard, archeological facts

- Colonial spirit; France in Indochina; founding of the EFEO (Ecole française d'Extrême-Orient, 1898, still extant)

$\rightarrow$ e.g. Angkor, Dunhuang...

- Fiction literature appears as comparatively much more secondary, and is treated with less scholarly respect

- With the advent of cinema, theatre was dislodged from its place as the first popular entertainment 


\section{COURRIER DES ILES}

- The Yellow-Millet Dream 黃梁夢

- Ma Zhiyuan 馬致遠 (c. 1250-1321)

- 1935

- Trad. Louis Laloy (1874-1944)

• "13th Century Taoist drama"

\section{LE REVE \\ DU \\ MILLET JAUNE \\ DRAMR TAOISTE DU XII SIBCLE \\ TRADUT DU CHINOAS

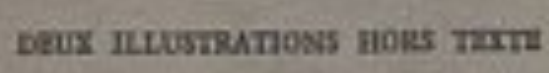

D E S C E E

DE BROUWER 
- Xixiang ji 西廂記

- The Story of the Western Wing, by Wang Shifu 王實甫 (fl. 12971307)

$\rightarrow$ rather than retranslated: adapted as novel

- 1928

- George Soulié de Morant (1878-1955)

- The Loving Oriole, Young Girl 13th Century Chinese Love Novel

CEORGE SOULIE DE MORANT

L'amoureuse Oriole, jeune fille

ROMAN D'AMOUR CHINOIS DU XIII' SIĖCLE

Avec dix illustrations chinoises 
- 1918-1921 Early Chinese Republican period

- Witnessed a similar trend towards rewriting of classical theater into novels $\rightarrow$

- Xixiang ji yanyi 西廂記演義 The Romance of the Western Pavilion

- Pipa ji yanyi 琵琶記演義 The Romance of the Stoty of the Lute

- Taohua shan yanyi 桃花扇演義 The Romance of the Peach Blossom Fan

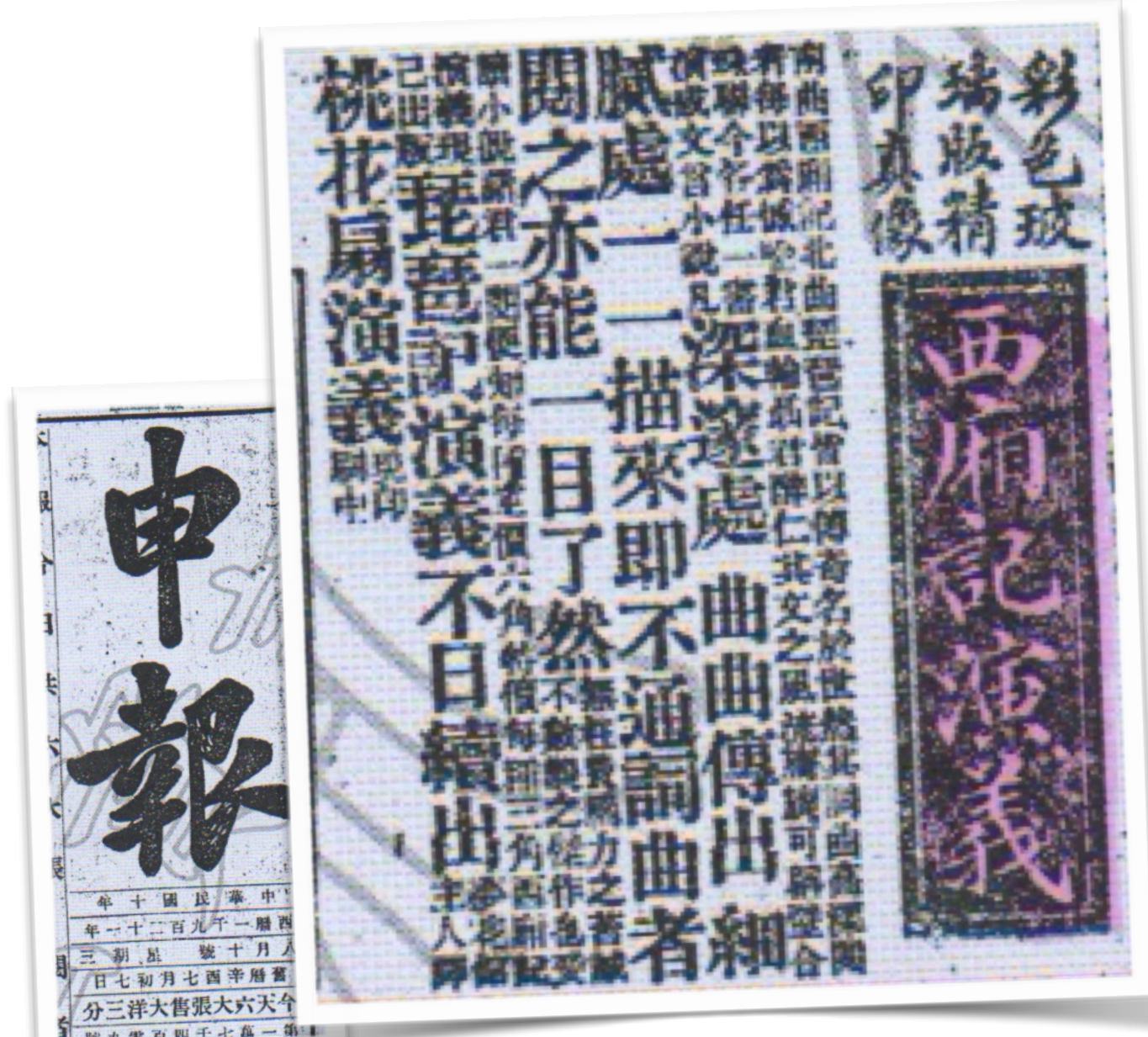


- 2nd half of 20th cent. to the present

- Huge effort in the field of translations of classical novels and short stories

- France is one of the Western countries that translates the most Chinese literature, classical, modern, and contemporary

- Scientific translation is valued in academic publications (compare, e.g., with the US)

- Few general interest for theater despite many scholarly research on theater

- One of the difficulties today with the reception of the theatre is that the public is more reluctant to read

$\rightarrow$ dialogued form, didascaly $=$ factors that give the impression that reading theatre is difficult

- There are too few cases in which translation of drama is motivated by a public performance 
- 牡丹亭 The Peony Pavilion

- By Tang Xianzu 湯顯祖 (1550-1616)

TANG XIANZU

Le Pavillan

aux piuaines

- 1998

- 1998: Kunqu 昆曲 performed onstage in Paris
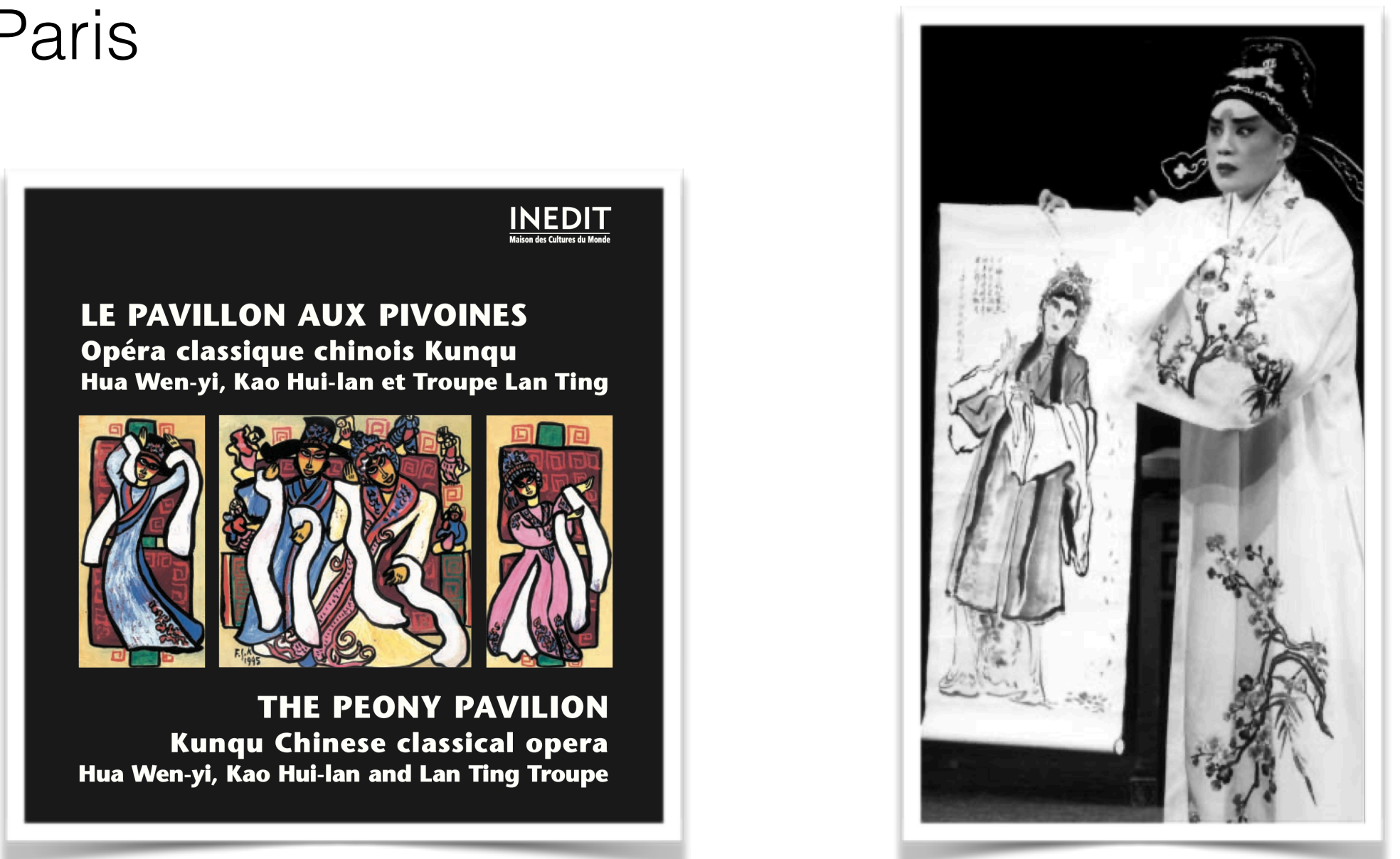

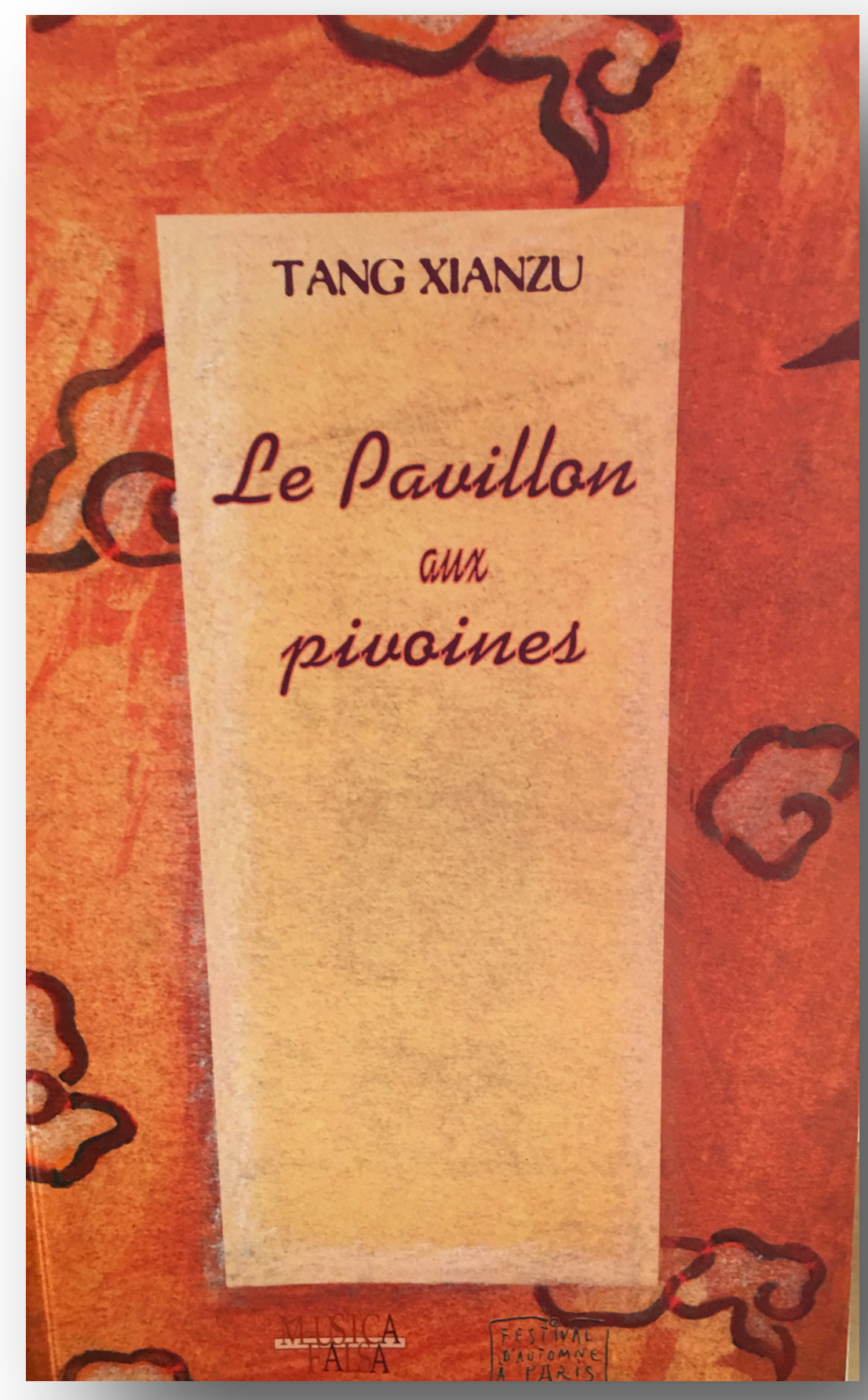




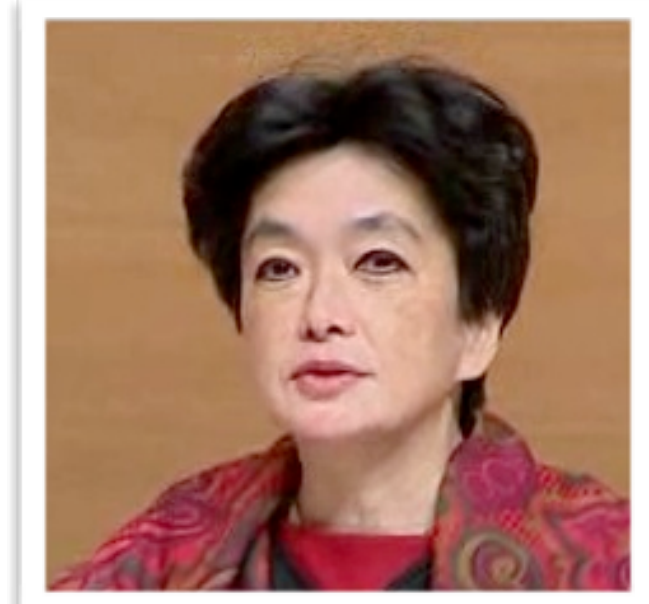

\section{LES BELLES LETTRES.com}

\section{NOTRE MAISON I NOTRE LIBRAIRIE ET SON BLOG I PRESSE I FOREICN RIIGHIS}

\section{- Anne Cheng 程艾蘭}

- Chair of Chinese Philosophy

$\rightarrow$ Series "Chinese Library"

\section{catalocuE}

Recherche rapide

Recherche avancée

\section{THÉMATIQUES}

Histoire et civilisation

Textes et études

Philosophie et sciences humaines

Arts

Théâtre

Religions / Théologie

Mythologie

Littérature française moderne et

contemporaine

Littératures étrangères

Dnócia

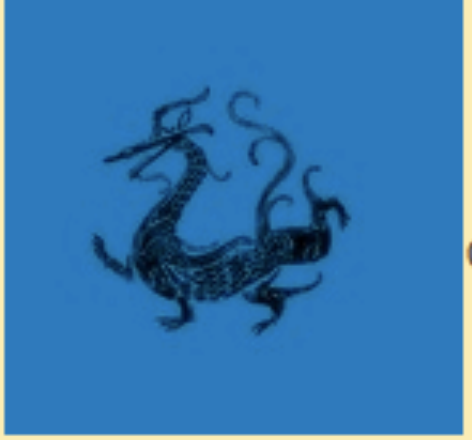

\section{Bibliothèque chinoise}

Collection dirigée par Anne Cheng et Marc Kalinowski

La « Bibliothèque chinoise $*$ a pour ambition de proposer les classiques de la littérature ch histoire, poésie, traités politiques et militaires, mais aussi médecine, astronomie, mathéma Les textes sont choisis pour leurs qualités littéraires, pour l'importance qu'ils ont connue d dans les ouvrages les plus représentatifs de l'immense production écrite qui caractérise cє chute du régime impérial en 1911.

Les textes sont proposés dans une version bilingue ; ils sont accompagnés d'une longue index) destinés à en guider la lecture et la rendre plus agréable.

L'entreprise est menée par des sinologues reconnus, qui travaillent sous la direction scien Chine du Collège de France, et de Marc Kalinowski, directeur d'études à l'Ecole pratique et médiévale.

- Collège de France 


\section{LES B E L LES LET T R ES}

\section{SOPHOCLE}

\author{
AJAX \\ GDIPE ROI \\ ÉLECTRE
}

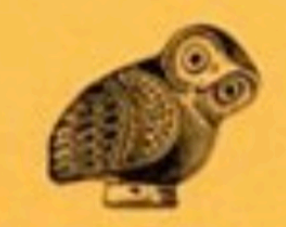

LES BELLES LETTRES

PARIS

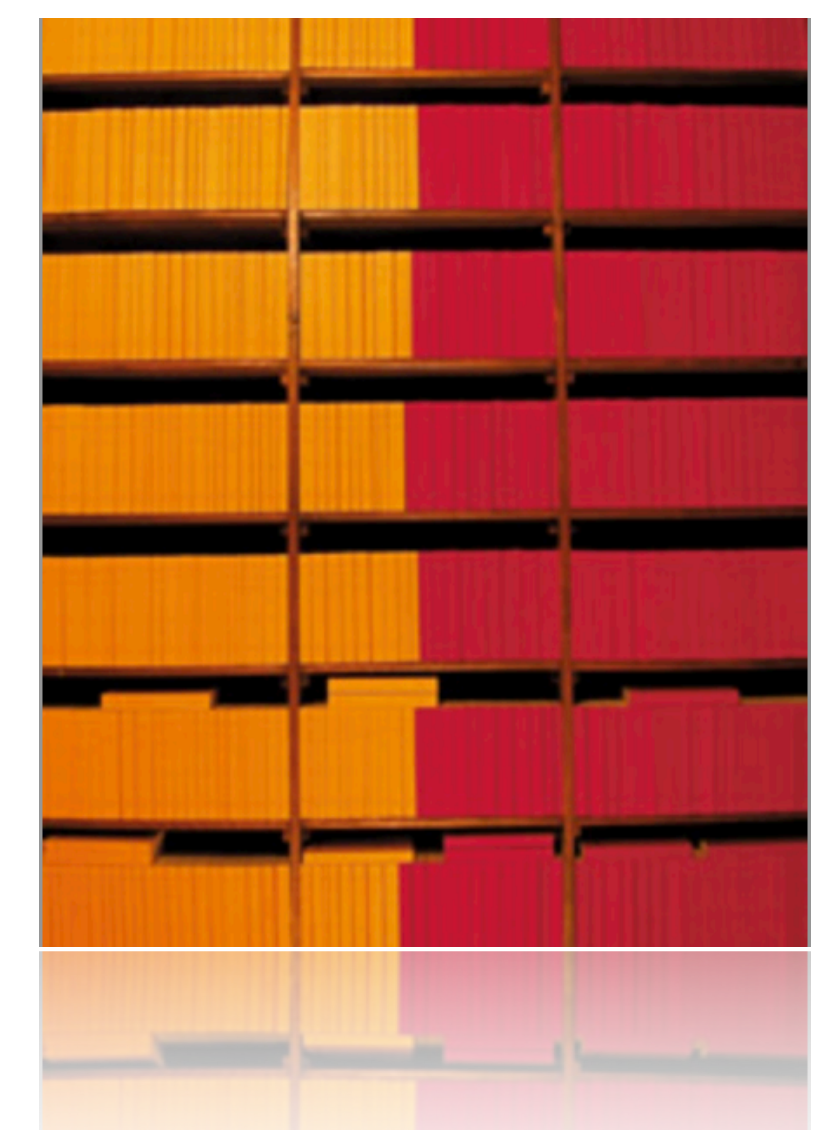

- Series of bilingual edition of all the Greek and Latin classics 
175 sante d'Éthiopie, tel le limon que le fleuve retentissant, le Nil en crue déverse dans l'onde salée, alors qu'il se rue contue les flots marins. A l'endroit des sourcils, on voit sur son front deux sortes de renflements ; au-dessous, son oeil s'empourpre, surplombant de haut ses anneaux, et son cou grisâtre se gonfle, tandis qu'il

180 siffle sans arrêt, à l'heure où, aux voyageurs qu'il trouve sur sa route, il imprime la mort, violemment courroucé. Il a quatre dents creuses par dessous, longs crochets enracinés dans les mâchoires, réservoirs à venin ; à leur base, une tunique

185 membraneuse les recouvre : voilà d'où il crache dans le corps de ses victimes son venin implacable.

Fasse le Ciel que ces monstres menacent la tête de mes ennemis ! Sur la chair, nulle trace de morsure n'apparaît, nulle inflammation d'cedème incurable, mais c'est pour la victime une mort sans douleur : un sommeil comateux amène à sa suite la fin de l'existence ${ }^{20}$.

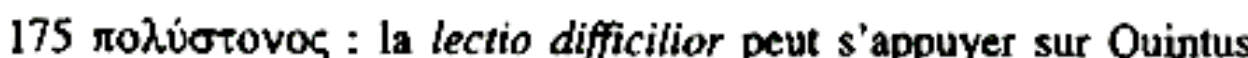

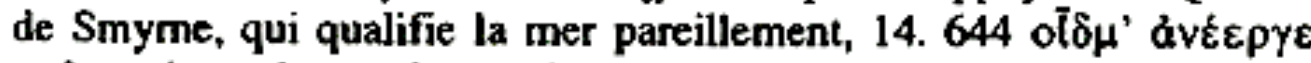

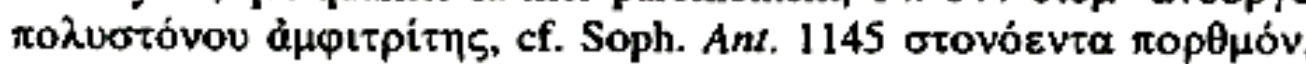

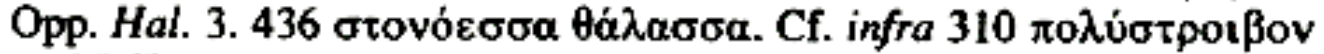

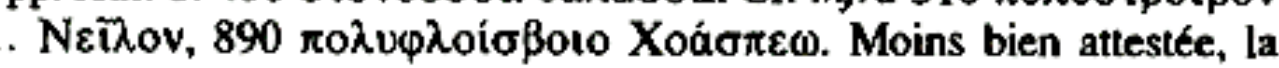
leçon ro $\lambda \dot{\sigma} \sigma t o \mu \circ$ s, beaucoup plus banale, semble être une conjecture (cf. Wilamowitz' 1. 191'140): $\Sigma 175$ b cite à l'appui D. P. $226 \varepsilon \pi \tau \dot{x} \delta$ tò

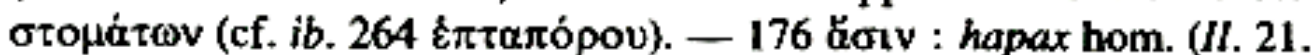
321) glosé lizúv (Ap. Soph. 45.11), comme le seul autre emploi poett. en dehors de N., cf. Opp. Hal. 3.433 et $\Sigma$ ad loc. Rapprocher infra 203

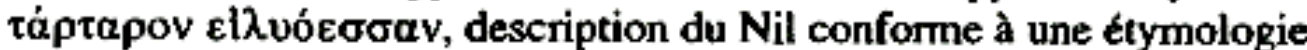
du fleuve (cf. n. ad loc.) ; et, pour le jeu étymologique, Opp. Hal. 1.

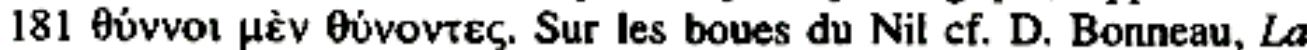
crue du Nil, Paris 1964, 65. - 177 akuvioloıv : 443 ; seules références littéraires pour ce mot du vocabulaire des parties du corps humain, aux attestations rares et tardives, \& sourcils n, cf. Poll. 2. 66

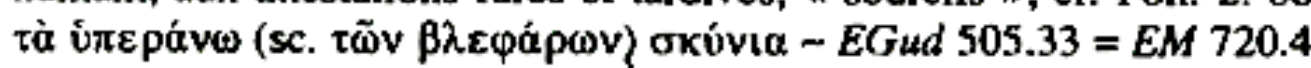

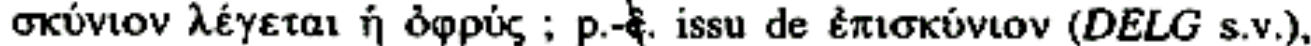
peau du front au-dessus des sourc is (Il. 17. 136), cf. Poll. ibid. $\sim$ Ruf. Onom. 17 (135.13). Les $\Sigma$ 443b font des deux mots des syn. désignant

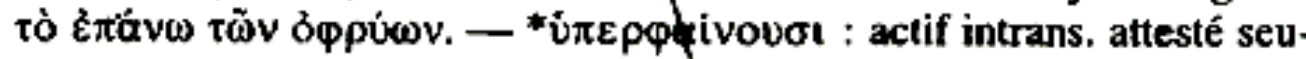
lement ici ; pour la construction auec l'accus. cf. Plut. Dion 39. 1

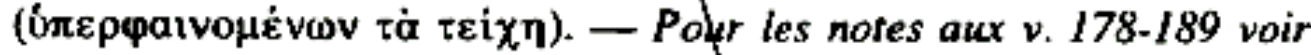
p. 97.

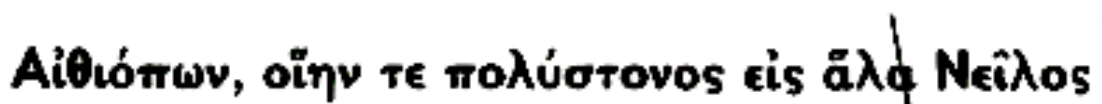

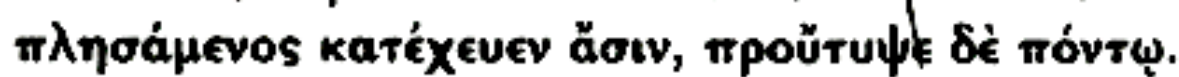

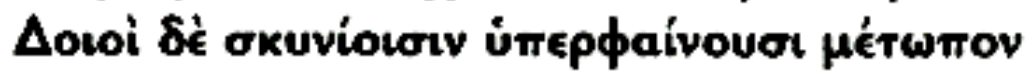

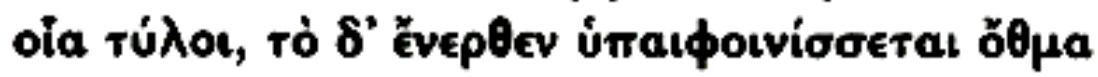

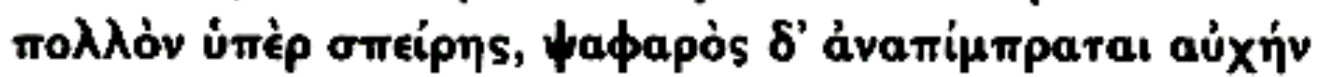

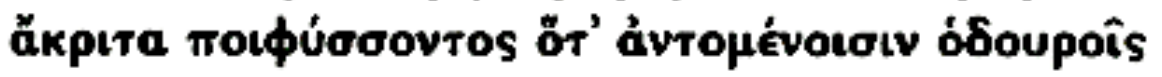

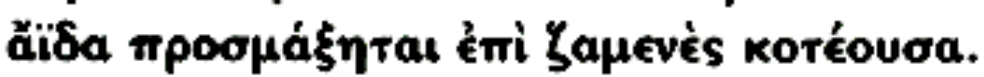

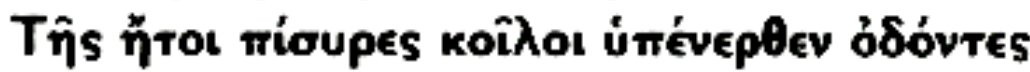

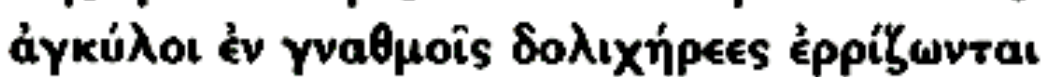

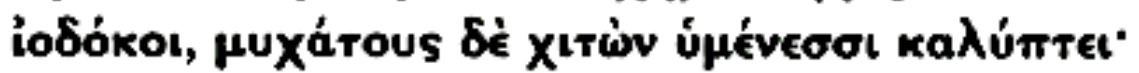

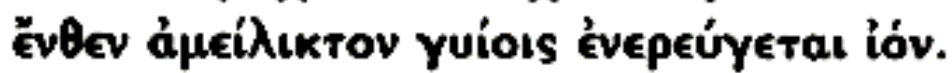

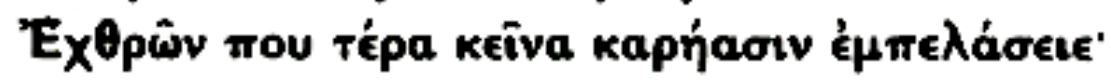

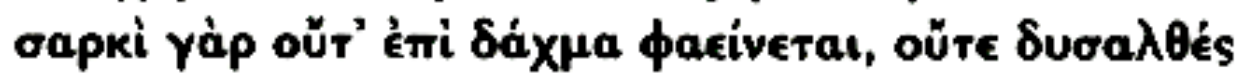

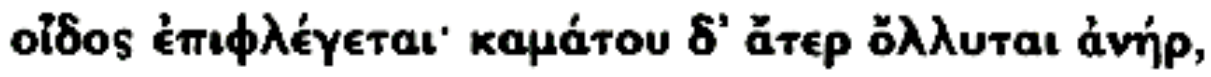

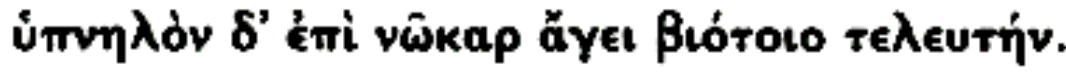

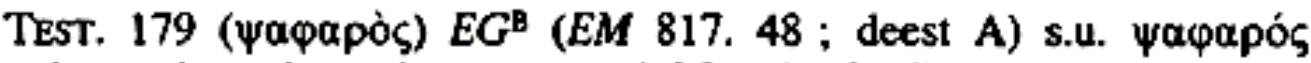

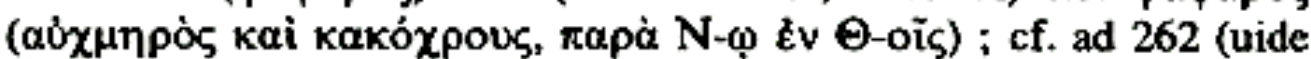
etiam 172, 369) || 182-185 respicere uid. Ael. 16. 40 fin. (ad oĩ $\pi$ a ser-

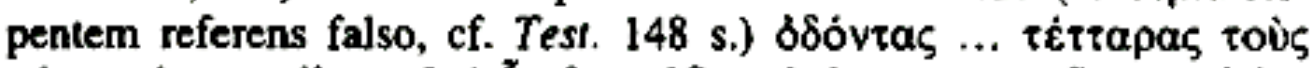

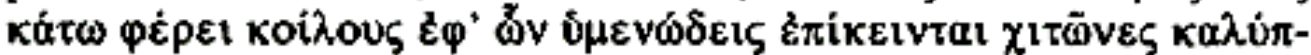

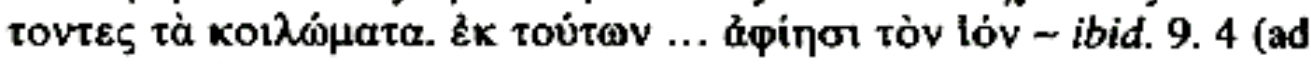

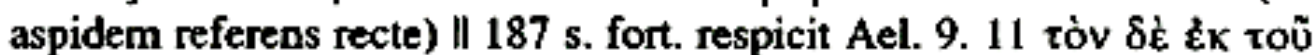

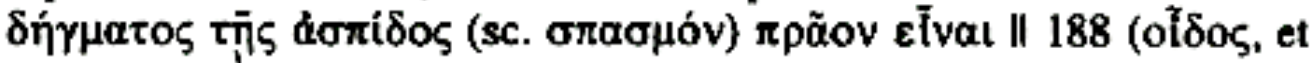

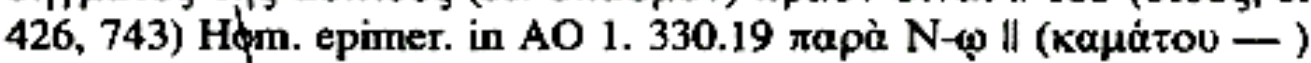
Ph. 16. 4 (22. 6) PAeg. 5.19 [21. 9] = Ps.D. 17 [73.9]) kahãs $\delta \mathrm{N}$ -

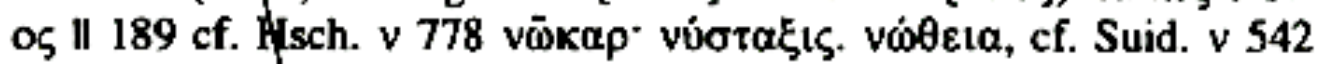

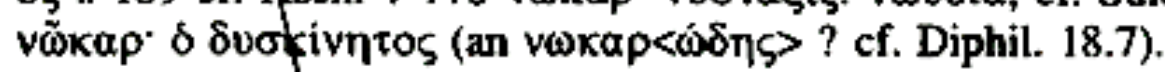

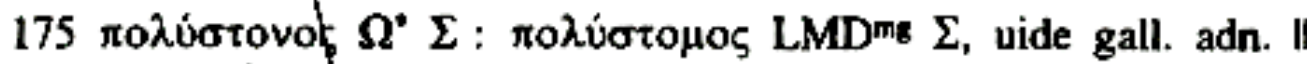

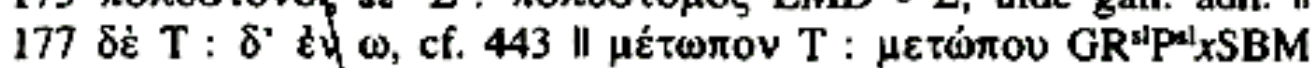

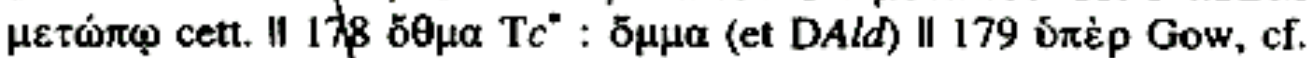

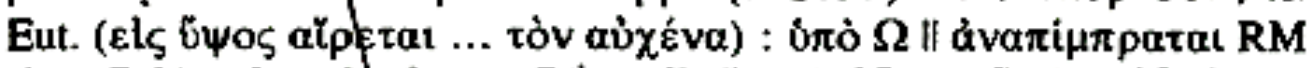

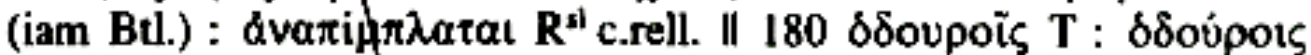

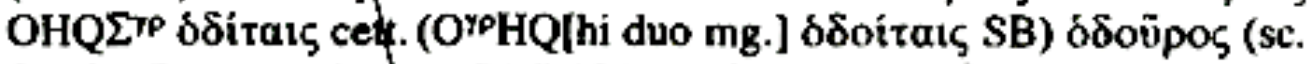

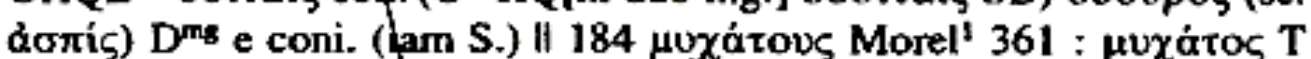

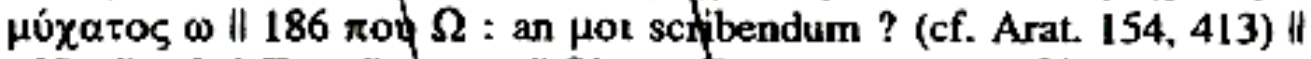

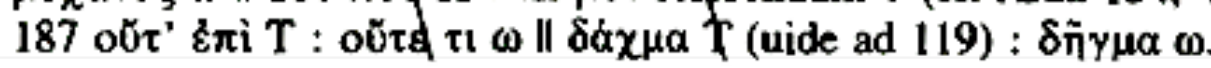




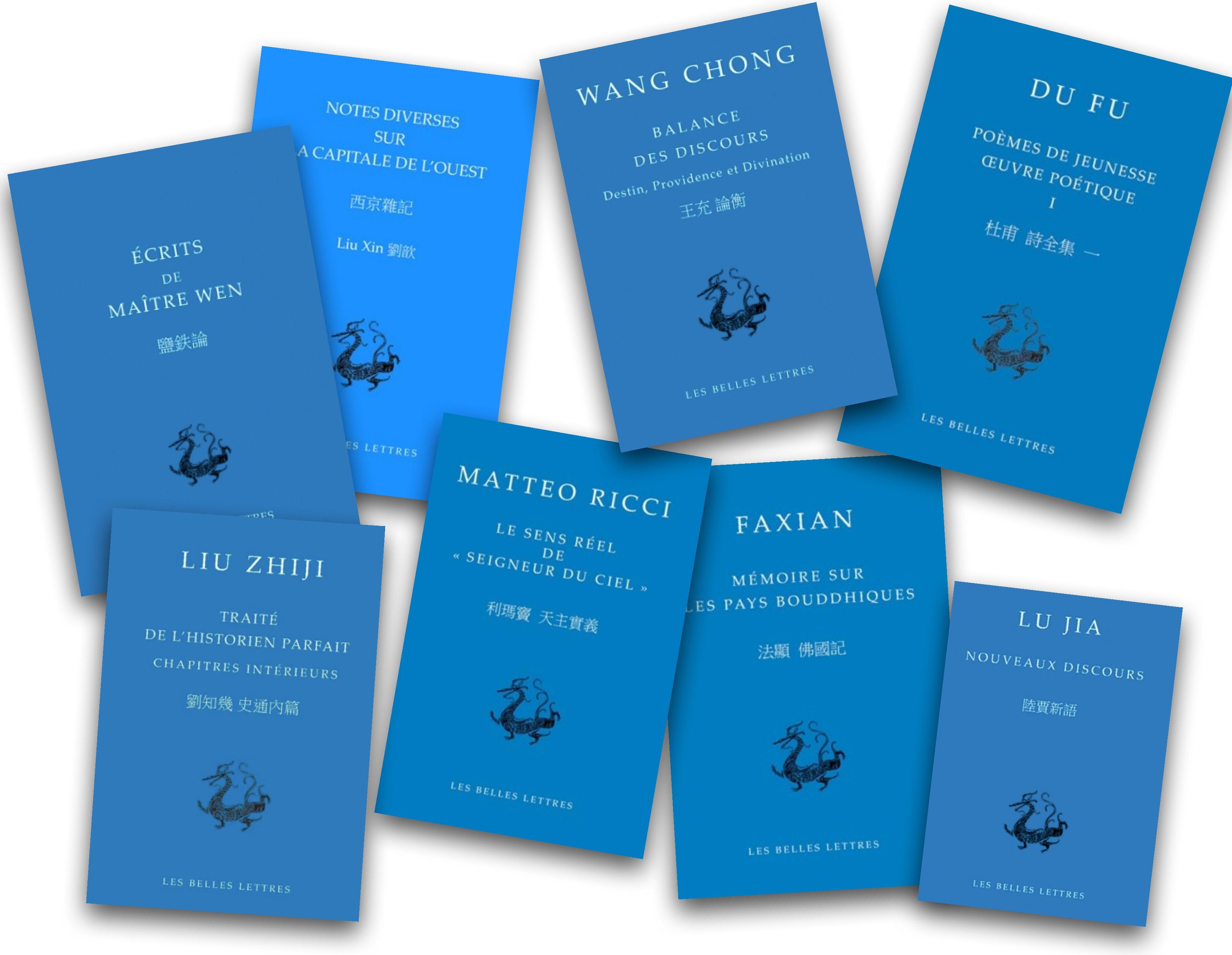




\section{WA NG SHIFU}

LE PAVILLON DE L'OUEST

\section{王實甫 西廂記}

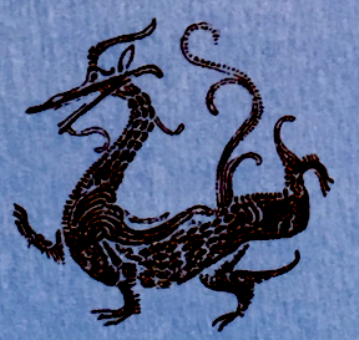

LES BELLES LETTRES

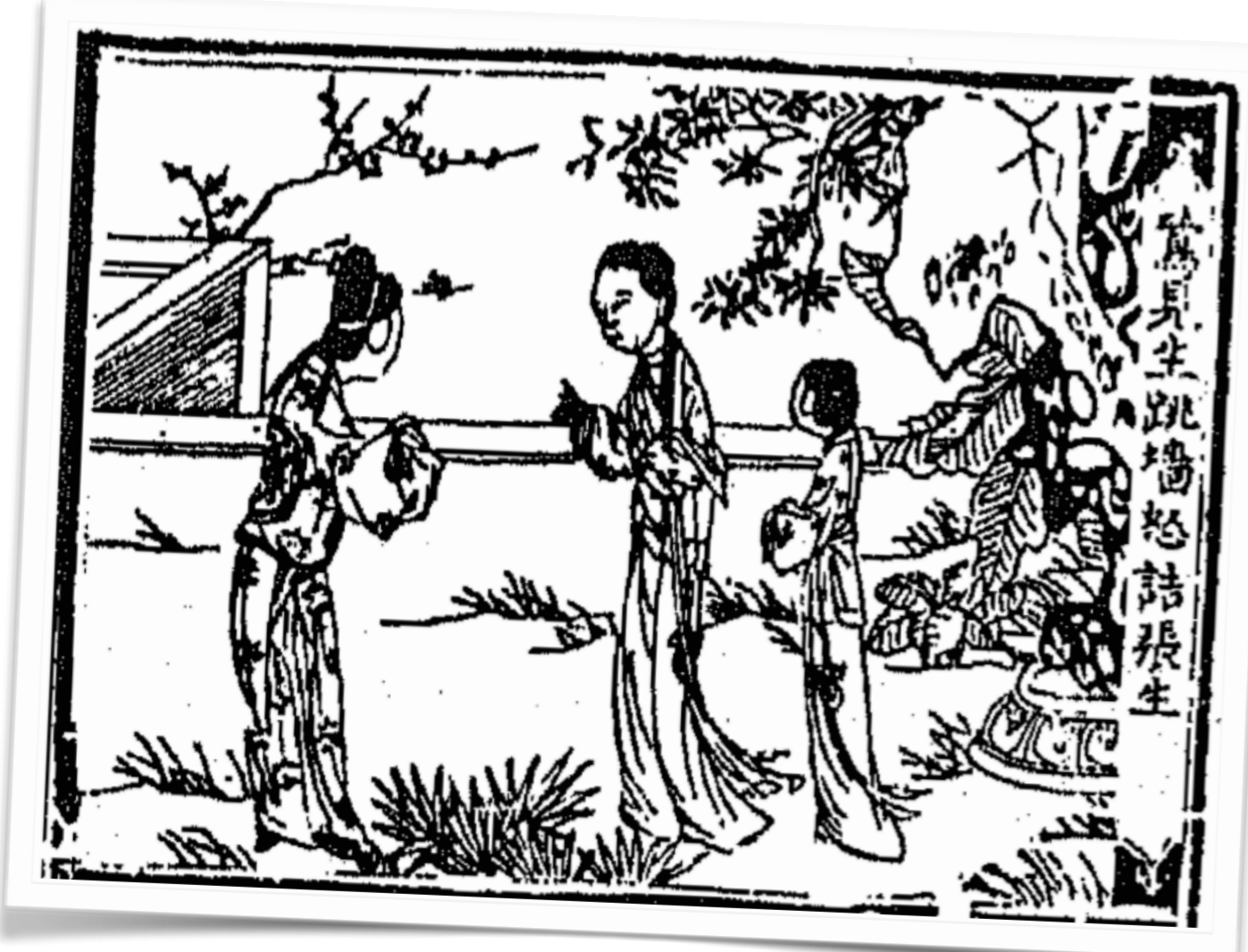

- Xixiang ji 西廂記 The Story of the Western Wing

- By Wang Shifu 王實甫 (fl 1297-1307)

- Transl. Rainier Lanselle (2015)

- First retranslation since 1872 (143 years) 
- 3 Yuan Plays

- Transl. Isabella Falaschi (2016)

- Among which:

- The Orphan of Zhao

$\rightarrow$ First retranslation since Stanlislas Julien's, 1834 (182 years) 
（旦云）

\section{風月天邊有,}

\section{人間好事無.}

\section{【小桃紅】}

\section{〔旦唱】}

\section{人間看波：}

\section{玉容深頊綉幃中,}

怕有人搬弄.

想嫦娥西沒東生：

\section{誰共怨天宮？}

\section{裴航不作样仙夢,}

108. La déesse de la Lune, Chang'e (Heng'e), figure archaïque dont la légende est relatée dans une foule de documents anciens, et restée très présente dans la mythologie populaire, est l'épouse de Hou Yi, l'Archer, personnage lié au soleil. Chang'e, immortelle de grande beauté, est condamnée à vivre solitaire dans son palais lunaire dit « des Vastes Frimas » (Guanghan gong). Elle a pour seule compagnie le lièvre lunaire, qui pile inlassablement, avec un mortier et un pilon de jade, le remède d'immortalité.

109. Pei Hang (dont l'existence est historiquement attestée, $f$ l. ca. 820) est le personnage central d'une nouvelle extraordinaire en langue classique (chuanqi) des Tang, simplement intitulée « Pei Hang », due à un auteur obscur du nom de Pei Xing ( $\mathrm{IX}^{\mathrm{e}} \mathrm{s}$.). L'histoire raconte comment, bachelier errant ayant échoué aux concours, Pei Hang rencontre en voyage une femme à la beauté fascinante, nommée Yunqiao, Houppe-de-nuage, mariée à un certain Pan. I tente de la séduire, mais elle ne cède pas à ses avances et lui laisse un poème mystérieux évoquant un événement qui se déroulera en un lieu dit le «Pont aux indigotiers ». À quelque temps de là, Pei Hang fait halte au « Relais du Pont aux indigotiers » (Lanqiao yi), dont le nom l'intrigue à cause de l'allusion du poème, et où il est servi par une ravissante fille de service, Yunying, Fleur-de-

\section{Premier rôle féminin}

La brise avec la lune existent dans le ciel,

Mais il n'existe rien de bon parmi les hommes.

\section{ת Petites fleurs rouges du PÊCher}

Premier rôle féminin chante

\section{Voyez ce monde humain :}

Celle dont le visage est fait de jade, cloîtrée au verrou derrière les tentures à broderies,

De peur qu'on ne la déshonore.

On évoque Chang'e, qui disparaît à l'ouest et renaît à l'orient : Y a-t-il une âme pour partager avec elle les peines du céleste palais $^{108}$ ?

Pei Hang est privé du rêve de voyage au pays des immortels ${ }^{109}$,

nuage. Il s'en éprend. Il propose à la vieille qui la chaperonne d'acheter Yunying pour en faire sa femme. Mais la vieille met une condition : qu'il pile pendant cent jours le remède dont elle (la vieille) a besoin, car elle souffre d'un « mal étrange ». Pei Hang accepte l'épreuve et n'hésite pas à se ruiner complètement, allant jusqu'à vendre son cheval et ses serviteurs, pour acheter le mortier et le pilon de jade, qui ne sont autres, en fait, que ceux du Lièvre de la lune (dont la légende, attachée au thème de Chang'e, dit qu'il a pour fonction de préparer le cinabre d'immortalité). Inlassablement il pile le remède (un cinabre magique que la vieille a obtenu d'un immortel) dans le mortier, le Lièvre de la lune venant en secret même lui prêter main-forte et continuer son travail à sa place la nuit, quand il dort. La vieille est finalement guérie par le remède que Pei Hang a préparé. Elle disparaît un temps dans les montagnes en compagnie de Yunying pour, au bout du compte, revenir et emmener Pei Hang en un palais éblouissant où il peut enfin épouser la jeune fille. Là, il revoit également celle dont il s'était épris en voyage, Yunqiao, qui n'est autre que la sœur aînée de Yunying. À la fin du récit, à la grotte du Pic-de-Jade (Yufengdong), Pei Hang devient, comme son épouse, un immortel. La nouvelle de Pei Xing connut, sous des titres comportant le plus souvent le nom du Pont aux indigotiers (Lanqiao), de nombreuses adaptations dans les périodes Song à Ming, notamment sous forme de pièces de théâtre (dès les Yuan), de contes en langue vulgaire sous les Ming, et constitua une vignette constamment citée dans la culture populaire. Ici, le thème de Pei Hang, amant fidèle prêt à tous les sacrifices pour obtenir sa bien-aimée, est étroitement associé à la légende, beaucoup plus ancienne, de Chang'e, déesse de la Lune : l'association s'appuie sur le thème, commun aux deux histoires, de l'élixir d'immortalité et de la fonction du Lièvre de la lune. Pei Hang pourrait devenir l'amant hypothétique qui pourra sortir Chang'e de sa caractéristique première dans la légende : le fait qu'elle est une belle inaccessible, éternellement enfermée, n'appartenant pas au monde des mortels. 
- "Retranslations place more emphasis on the source text language and culture because, over the course of time, these elements can become much better known and understood by readers."

(Cadera, 2017)

- "It is said that the "half-life" of a translation is thirty years, and that translations age more quickly than the original. Thus re-translation can be seen as a kind of historical revision, a modernization of the text to reflect changes in language and context."

- "Another justification for re-translation is that a new edition of the source text has been published and replaces earlier versions as the new standard reference."

(Lowe, 2014)

$\rightarrow$ These are valid arguments for my retranslation of The Story of the Western Wing 
- The very fact that there exists a Chinese bilingual series shows that there is sufficient readership capable of reading the original text

- Stanislas Julien's translation was outdated and in many ways faulty due to the limitations of the philological means of his time

- Julien worked on a well-known 17th-century edition of the play in 16 acts, whereas I translated an earlier (year 1498) version in 21 acts, much closer to what may have been the original state of the play 
+ Additional factor

- A modern reprint of the translation by Julien had been published

- The "recycling" of an outdated translation for commercial considerations is always something problematic

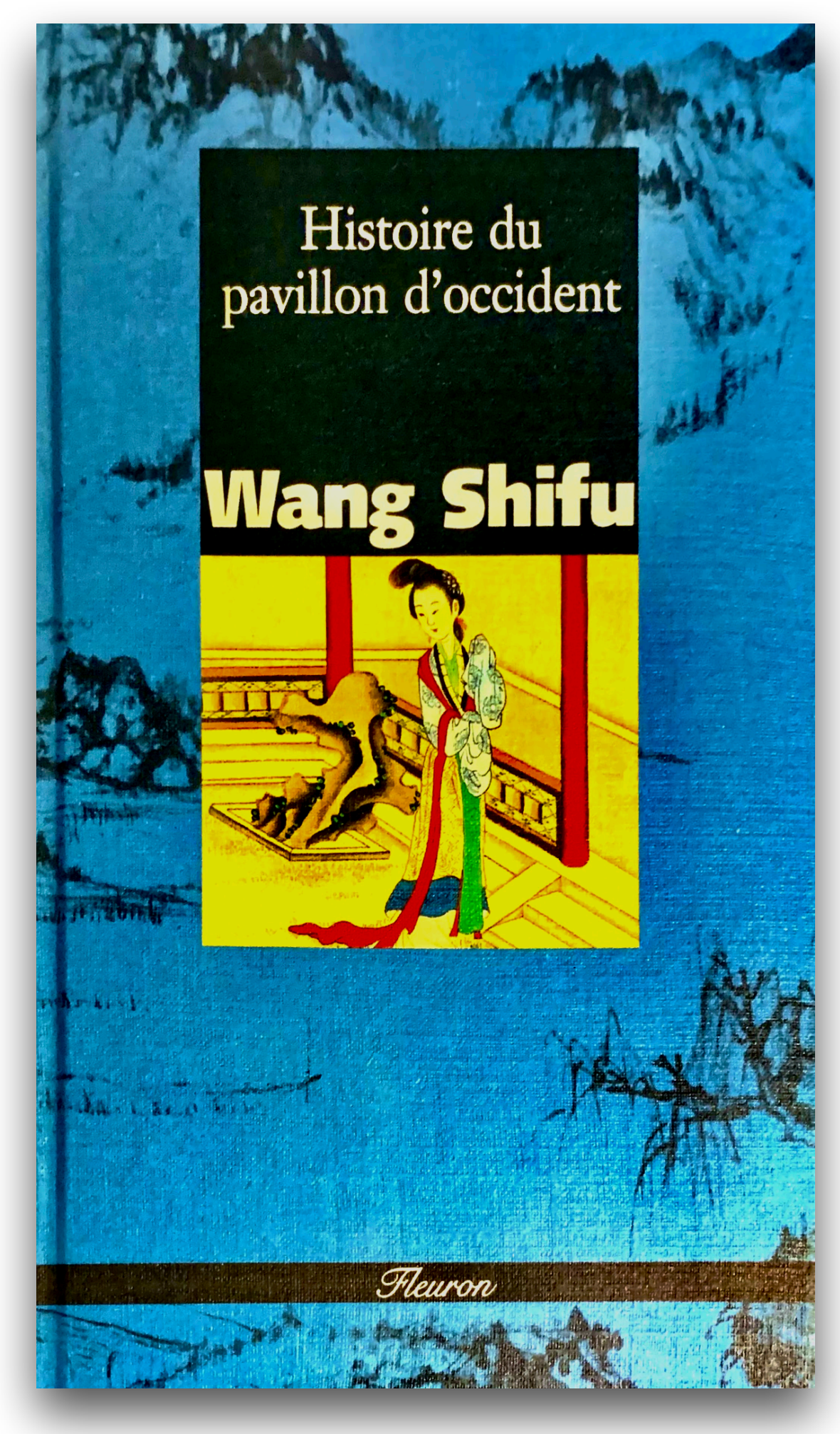

1997 reprint

Preface by André Lévy 


\section{THE MOON AND THE ZTHISR}

THE STORY OF THE WESTERN WING

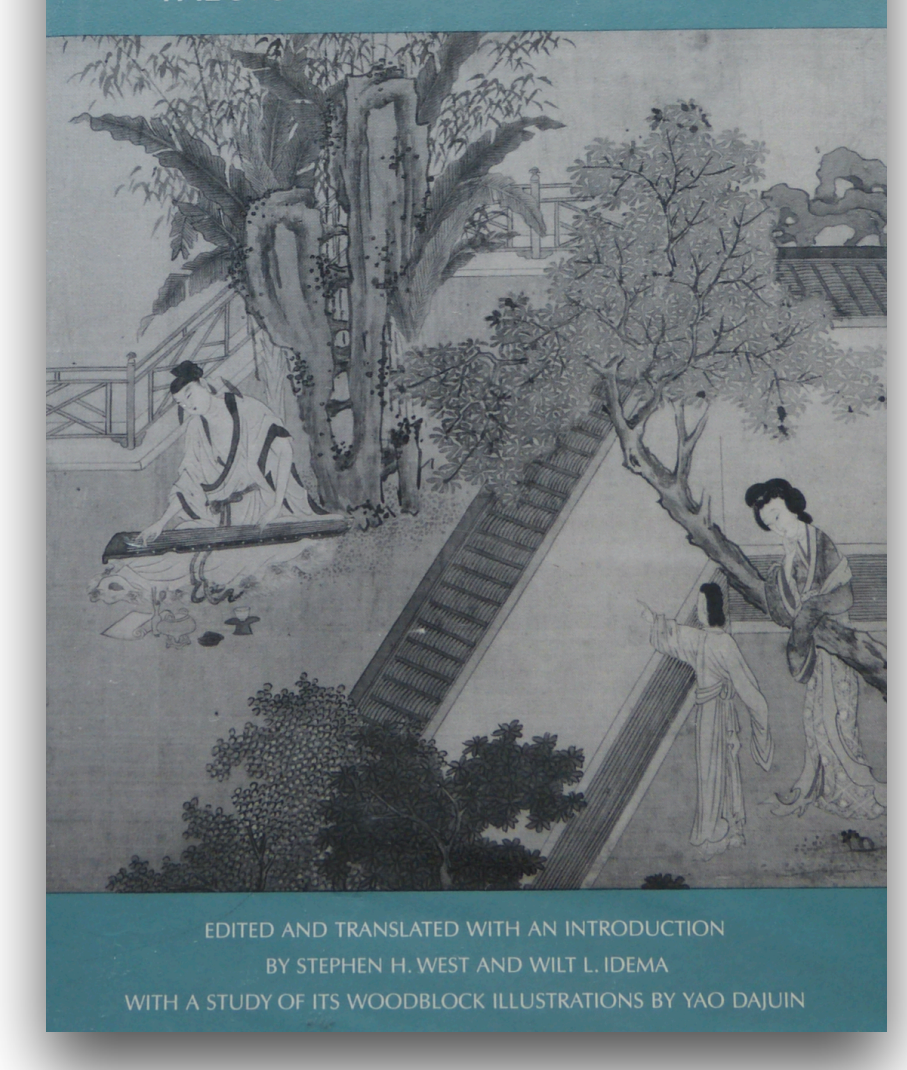

1991 edition
+ Additional factor

- A masterful translation of the play had been published in English, by Wilt Idema in 1991 (repr. 1995)

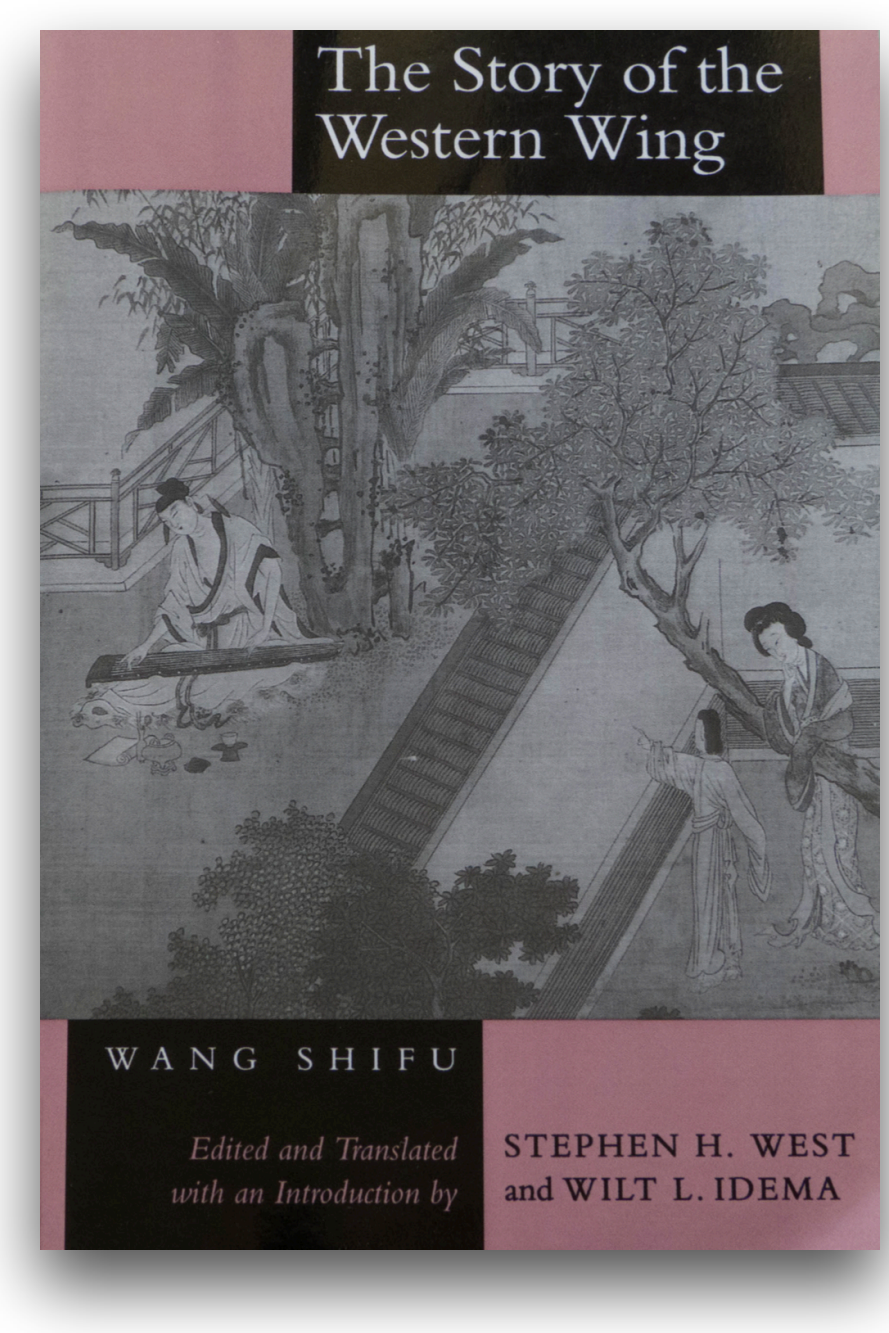


- "Retranslation is a polemical act by nature."

(Popovič, 1976)

- "What makes retranslating different from other translation is that there exists at least one previous translation, and a previous translator. The figure of the first translator, either as a real-life person, as a mental image or a textual construction, is one obvious potential source of dependency for the second translator and the readers of the second translation alike, and this influence, or the careful avoidance of any influence, may affect the translation process in a number of ways."

- "The process is initiated because there is an understanding that the existing translation is somehow faulty: too old, too outdated, too free, too domesticated or too foreignised and so on."

(Koskinen \& Paloposki, 2015)

$\rightarrow$ «Anxieties of influence: The voice of the first translator in retranslation » 


\section{$\rightarrow$ In a bilingual edition, another voice, that of the author, is directly present on the page}

【落梅風】
『生唱】
你硬撞入桃源路,
不言箇誰是主,
被東君把你箇蜜蜂児攔住.
[云］
不信, 呵 !
[唱］
去那緑楊影裏聴杜宇
一聲道 《 不如歸去 》.
(外云)
那厮差不去呵, 祇候拿下！
(净云)
不必拿 ! 小人自退親事. 與張生罷.

\section{ת LE VENT QUI FAIT TOMBER LES FLEURS DE PRUNUS \\ Etudiant chante}

Toi qui prétends forcer la route de la source aux Pêchers ${ }^{82}$, Tu ignores qui est le maître ici,

Mais te voici barré, mouche à miel ! par le Seigneur de l'Orient,

$$
\text { [Parle] }
$$

Et si tu ne le crois pas, hé!

\section{[Chante]}

Va dans l'ombrage des saules écouter le coucou Dont le chant est plein de «mais retournez chez vous ! $»^{83}$.

\section{Extra}

Que ce salopard disparaisse, sans quoi j'ordonne à mes gardes de s'emparer de lui !

\section{Bouffon}

Pas la peine! Je renonce à mes prétentions. Qu'on la donne à Zhang-sheng et qu'on n'en parle plus. 


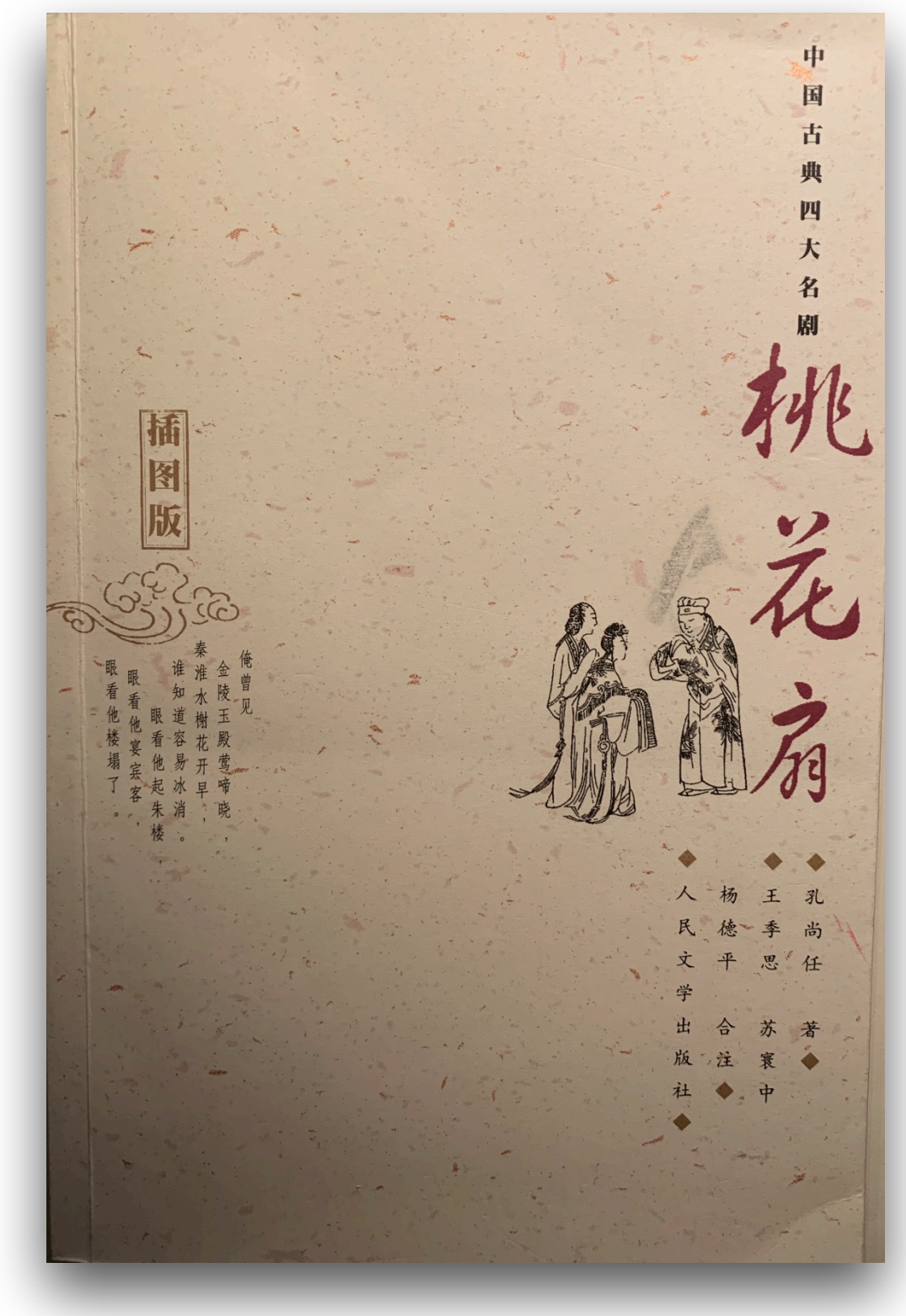

- Current translation:

- Taohua shan 桃花扇

- The Peach Blossom Fan

- By Kong Shangren 孔尚任 (1648-1718)

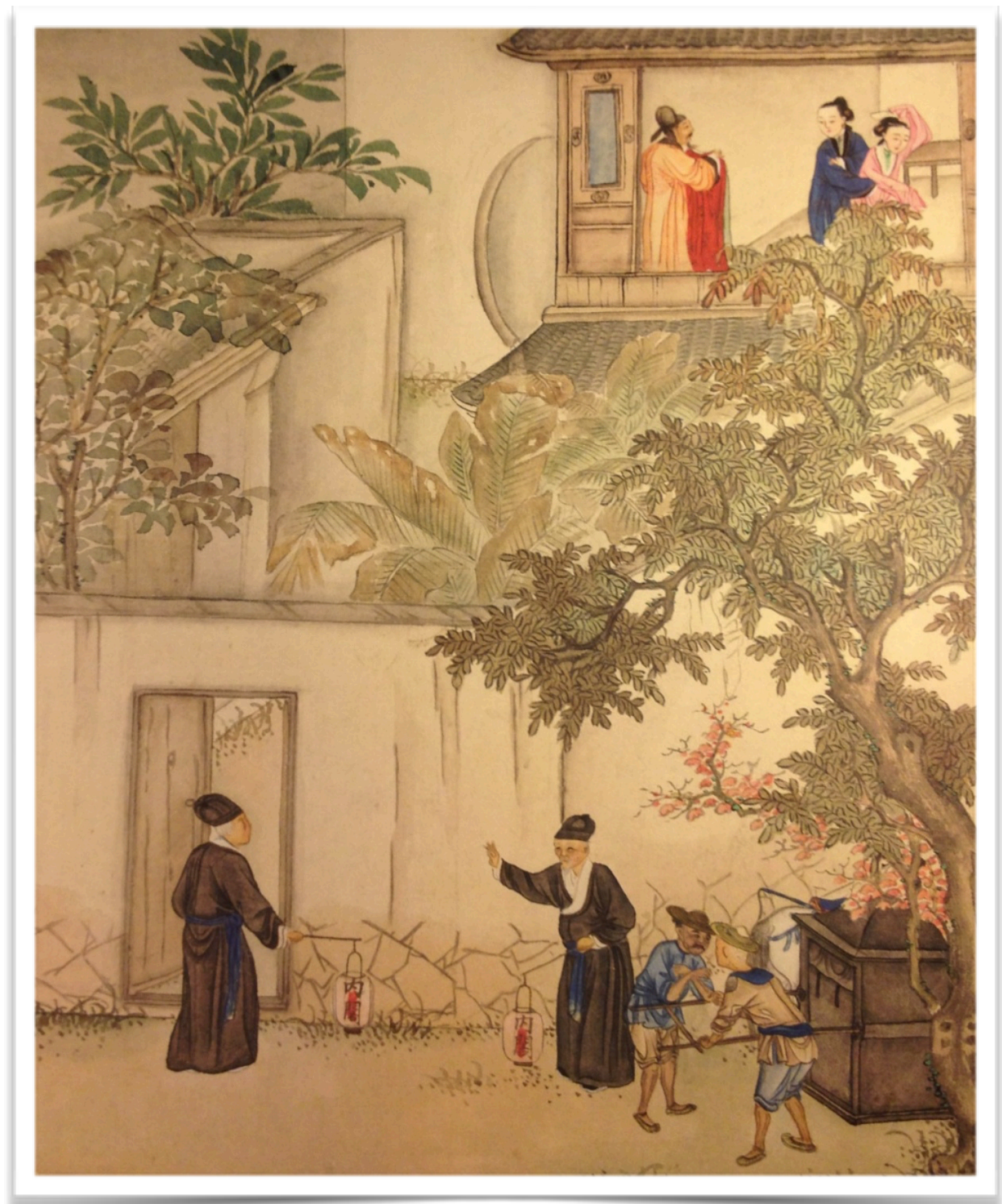


- Historical play

- Southern Ming (1644-1662)

- Rewriting of history as fiction

- 3-year research and teaching program

- First fully annotated translation in an European language 
Chapitre Un, Volume Premier

Scène de prologue : Propos avant-coureur (先聲)

Ere Kangxi, an $\ddot{z i a z i, ~ h u i t i e ̀ m e ~ l u n e ~}$

( 9 septembre -8 octobre 1684$)$

s Le papillon amoureux de la fleur (Róle masculin secondaire, bonnet de feutre, robe de letrte, barbe et moustaches blanches, monte en scène) Comme antiquité je
me pose là, y'en a pas deux comme moi. Je n'ai point besoin d'être de jade ou de bronze Pour avoir la figure toute patinée. Mes débris d'âmes subtiles, mes reliques d'âmes terrestres, ne réclament pas de compagnie; Que mes contemporains me montrent du doigt, me regardent de haut, je n'en ai cure, croyez-le bien.

Les vieilles rancœeurs qui naguère m'occupaient tant, d'un coup de pinceau je les ai biffées, Là où il $\mathrm{y}$ a du vin et des chansons, Je prends racine - sur le lieu je ne suis pas regardant. Les d'aller quérir, du ginseng, je ne sais quel rare fruit ${ }^{1}$ ?

Le soleil resplendit sur ce siècle digne de Tang et de $\mathrm{Yu}^{2}$, Les fleurs s'épanouissent en cette année où débute un cycle nouveau ${ }^{3}$; Dans les montagnes point de brigands, aucun gredin en vue, Sur terre partout les dieux et les immortels sont.

Le vieux bonhomme qui vous parle était autrefois assistant de cérémonie à la Cour des sacrifices impériaux ${ }^{4}$. Mon rang n'était pas particulièrement illustre, et mon nom souffre fort bien de demeurer caché. S'il est pour moi un grand motif de satisfaction, c'est d'avoir pu échapper aux malheurs et aux calamités, et d'avoir vécu jusqu'en ma quatre-vingt-dix-septième année, ayant été témoin de bien des prospérités et bien des vicissitudes. Or voici qu'en cette année de cycle nouveau de suprême origine $e^{5}$ les Yao et les Shun ${ }^{6}{ }^{\prime}$ 'avancent hors du Palais pour recevoir les audiences, les Yu, les Gao sont

1 Selon la légende le ginseng fleurirait après trois mille ans, produirait un fruit (renshenguo) trois mille ans plus tard, lequel arriverait à maturité après encore trois mille ans. Comprendre : à quo Digne de Tang Yao $Y$ Shun Yao et

avant les dynasties, d'après un pt Shyn, les deux plus grands des sages souverains de l'âge 3 Littéralement en cette année iligzi, celle annoncée dans la date au début de la scène : 1684. L'année iigzi est la première d'un nouveau cycle sexagésimal. Comprendre : nous sommes dans une 4 Hucker 6145

5 Shangyuan jiazi : cette année n'est pas seulement une année marquée des signes cycliques jiazi, soit la première d'un nouveau cycle sexagésimal (note 3), elle est en même temps la première année d'un super-cycle de cent quatre-vingts ans. Ces super-cycles sont divisés en trois sous-cycles sexagésimaux, dont la première année, marqués des signes jiazi, est respectivement appelée

"chonge or la 61e année) et * origine inférieure " (xiayua la 121e année). Comprendre ici au sens emphatique de $:$ nous sommes dans un temps de renouveau et de prospérité tel qu'on en voit 6 Voir note n. 2 . aux affaires ${ }^{7}$, les quatre populations ${ }^{8} \mathrm{~s}^{\prime}$ occupent dans la joie et les cinq céréales ${ }^{9} \mathrm{se}$ récoltent en abondance. Nous sommes aujourd hui en la vingt-troisième année de l'ère

(Une voix hors de la scene) Et quels sont-ils donc ces signes, s'il-vous-plaît ?

11. Du Fleuve est sortie une carte, de la Lue apparut un écrit ; l'Etoile de splendeur s'est mis à briller, les Nuages de félicité se sont fait jour ; la Rosée suave s'est déposée, un doux nectar est tombé en pluie ; alors que les phénix des deux sexes s'assemblaient, l'on a vu paraître les licornes; les gousses de félicité ont crû, les champignons d'immortalité ont poussé ; la mer s'est trouvée sans vagues et le fleuve Jaune a présenté des eaux limpides ${ }^{12}$. Tous ces signes furent vagues et le fleuve Jaune a présenté des eaux limpides $^{12}$. Tous ces signes furent presents en même temps, sans qu'il en manquât un, n'y a-t-i-il pas de quoi se réjouir ? Le vieil homme qui vous parle, heureux témoin d'un siècle si florissant, a parcouru librement les diverses contrées, et c'est ainsi qu'hier au jardin dit de la Paix suprême, il lui été donné d'assister à une représentation d'un chuangai' nouveau, intitulé L'Eventail aux fleurs de pêcher, qui rapporte des faits récents s'étant déroulés dans la Nankin des dernières annees du règne des Ming. Il nous parle des passions nees de rencontres et de séparations, évoque les transports et

$7 D$ 'après la vulgate confucéenne ici invoquée, Yu, ministre de Shun, régula les eaux débordantes du fleuve Jaune, se révélant un ministre capable - à tel point que Shyn le prit pour successeur, (de la justice) de Shup avant de devenir conseiller de $\mathrm{Yu}$ lorsque celui-ci devint roi fut lui aussi parangon de vertu et de sagesse. Sous son magistère, on ne déplorait aucune injustice et l'on n'avait point besoin de recourir à des supplices cruels. Comprendre : dans ce temps présent où règne le meilleur des souverains, les plus sages ministres le secondent.

8 Dans l'ordre hiérarchique décroissant : les clercs, les paysans, les artisans, les commerçants. Plusieurs listes possibles, par exemple : le riz, le haricot de soja, le blé, le millet commun et te ${ }^{10}$ Sous le règne de l'empereur connu sous son nom de temple de Shengzu, le Saint ancêtre, nom de naissance Aixinn-jiaolug Xuanxe, 1654-1722, r. 1661-1722, quatrième empereur des Qing.

11 En Chine on compte sur ses doigts non en les étendant, mais en les repliant.

2 Autre synecdoque dun temps exceptínnelement faste, conjuguant comme par miracle un historique, le plus souvent à partir d'un locus classicus. Le chiffre huit est lui-même faste, et partiellement lié au bouddhisme. La Carte du Fleuve (Hettu) fut apportée à Euxi, au début des temps civilisés, par un cheval-dragon sorti du Fleuve jaune ; ses signes lui inspirèrent les premiers trigrammes. L'Ecrit de la LLog (Lyoshu), qu'apporta, tracé sur dos, une tortue sortie de la rivière Lugo d'administration idéale. Plusieurs livres historiques évoquent, quelquefois en les associant, l'Etoile de splendeur (Jingxing) et les Nuages de félicité (Qingyun) comme attestant qu'un gouvernement vertueux est aux affaires. Idem pour l'apparition de la rosée suave (ganlu), ou la pluie de nectar (gaoyu), bienvenue après la sécheresse. Phénix (fenghhyang) et licornes (gilin) apparaissent, c'est connu, quand un Sage est sur le point de venir en ce monde. Idem dans le doomaine végétal, avec les gousses de felicité (mingjia), produisant une graine par jour chaque première quinzaine de chaque représentée, sculptée, sur les marches cérémonielles du palais impérial, le champignon d'immortalité (zhicąe, lingzhi) étant l'une des plantes miraculeuses le plus communément évoquées. Enfin les macko-eiléements de la géographie s'en mêlent aussi : du temps du roi Victorieux, Chengwang fondateur des Zhou, la mer resta trois ans sans tempêtes, tandis qu'un gouvernement a même d'amener à l'idéal de la Grande paix est capab te rendre limpides ${ }^{3}$ La a relation d'étrangté e, le chugani le genre thé theatral qui fait fureur depuis les Ming, et dans 
The

Peach Blossom Fan

By K'ung Shang-ien

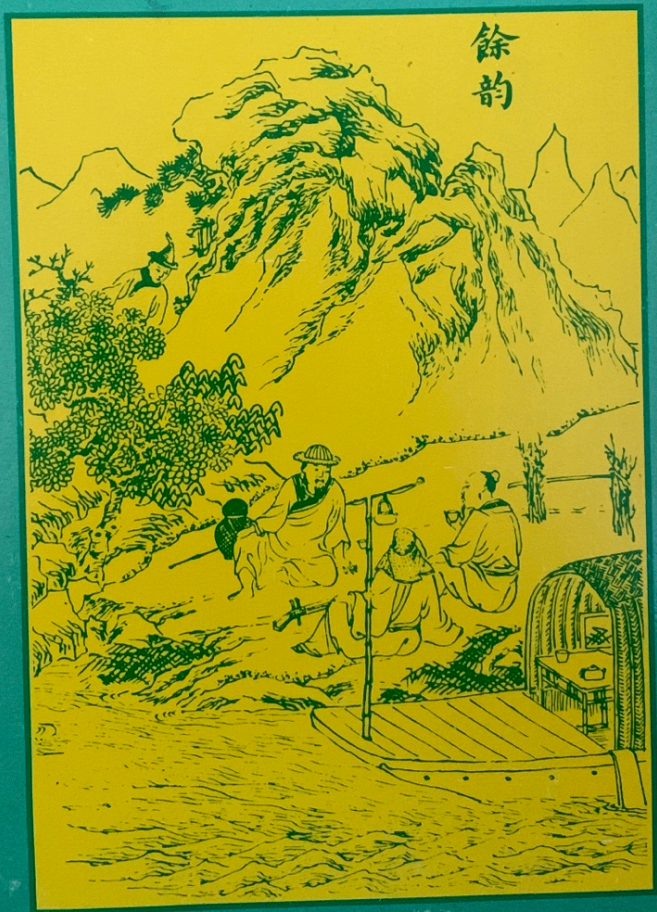

- Previous English translation/ adaptation by Harold Acton, 1976

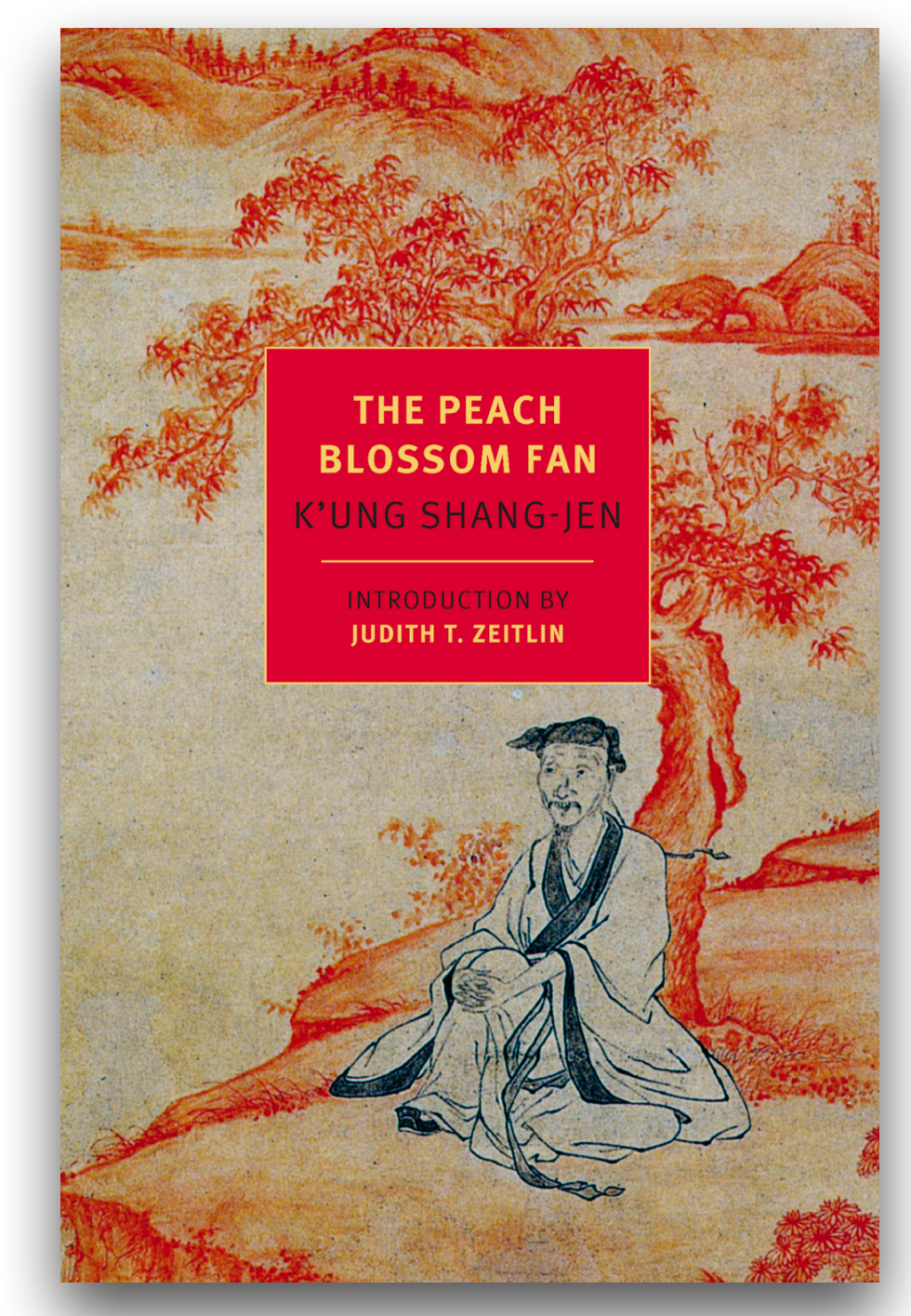

Repr. 2015

Preface by Judith Zeitlin 
Concluding remarks 
- "Rewriting is potentially subversive because it always manupilates and "updates » the original to some extent"

(Lefevere, 1992)

$\rightarrow$ This has never been more true than with the first, imperfect, translation of the "Orphan of Zhao"...

- If only modern, 'perfect', translations had even a fraction of its impact... 
- "The first translation is a "hesitant" first draft that will later be improved in new translations."

- [Furthermore,] "great translation can only be made by a great translator."

(Berman, 1994)

- "The one who re-translates is not just dealing with one single text, the original, but with two that occupy a specific space ... one can say that it is in this space that translation produces its masterpieces. First translations are not (and cannot be) the greatest" 
- "Great translator": a weak concept

- It creates a kind of mystique of retranslation, as if it were a dialectic and finalist relationship between one source text and one target text to be, without external factors

- "[...] Specific, extratextual causes of translation"

- Factors of "ideology, economics and the subjectivity of the translator".

(Venuti, 2004, criticizing Pym, 1998)

$\rightarrow$ Cf. Sharon Deane Cox in her criticism of Berman \& and his "Retranslation Hypothesis" (RH) 
- "Berman (1990) maps out [...] a particular pinnacle of accomplishment: the 'grande traduction' or 'great translation'. In keeping with Goethe's teleological reasoning, the great translation 'brings the original, previously concealed by initial translations, back to light and restores its meaning' $[\ldots]$, while 'setting an inimitable precedent for contemporary or subsequent translation activity' $[. .$.$] . At this lofty point, all great translations have$ one thing in common in that 'they are all retranslations' [...], since only the passage of time and the accumulation of experience can supposedly pave the way to such a feat of illumination and restoration in the service of the source text." 
- This march [towards "progress", or "perfection"] is at once mechanistic and anonymous, and should therefore be regarded with some degree of suspicion. To reprise Berman's own cutting lexicon, there is a certain irony in the fact that this approach is 'blind' to the material conditions of translation production, namely to the external influences which exist beyond the confines of the text. Moreover, the idea that one (re)translation will beget a closer retranslation presumes the presence of a symbiotic link between successive versions and precludes the possibility of a move backwards. There is always the chance that a given retranslation has been carried out without a priori knowledge of an antecedent $[\ldots]$.

(Deane-Cox, 2017) 
- This brings us to be critical towards the ST/TT dichotomy, as a practioner of translation as well as academic reflecting on translation

- Cf. Jean-René Ladmiral: Sourcier ou cibliste. Les profondeurs de la traduction [Source or Target-oriented. The Depths of Translation] (1986-2014)

- "Sourcerer" vs./ "Targetter"

- This dual model appears outdated

- Retranslation is a multifactorial endeavor:

- the state of the intercultural debate at a given time

- ideological factors

- the state and expectations of the related discipline (here: sinology)

- the (more or less) implicit presence of other texts:

- "the voice of the first translator" (and subsequent translators)

- translation(s) in other languages

- presence of previous editions on the market with various degrees of authority... 


\section{謝謝聆聽！}

\section{Thanks for your attention!}

rainier.lanselle@ephe.psl.eu 